Agroforestry Systems 38: 3-50, 1998.

(C) 1998 Kluwer Academic Publishers. Printed in the Netherlands.

\title{
Biophysical interactions in tropical agroforestry systems*
}

\author{
M. R. RAO ${ }^{1, *}$, P. K. R. NAIR ${ }^{2}$ and C. K. ONG ${ }^{1}$ \\ ${ }^{1}$ International Centre for Research in Agroforestry, P.O. Box 30677, Nairobi, Kenya; E-mail: \\ m.rao@cgnet.com; c.ong@cgnet.com; ${ }^{2}$ School of Forest Resources and Conservation, IFAS, \\ University of Florida, Gainesville, Florida 32611, USA; E-mail: PKN@gnv.ifas.ufl.edu \\ (* Corresponding author)
}

Key words: boundary plantings, hedgerow intercropping, improved fallows, parkland systems, sequential systems, simultaneous systems

\begin{abstract}
The rate and extent to which biophysical resources are captured and utilized by the components of an agroforestry system are determined by the nature and intensity of interactions between the components. The net effect of these interactions is often determined by the influence of the tree component on the other component(s) and/or on the overall system, and is expressed in terms of such quantifiable responses as soil fertility changes, microclimate modification, resource (water, nutrients, and light) availability and utilization, pest and disease incidence, and allelopathy. The paper reviews such manifestations of biophysical interactions in major simultaneous (e.g., hedgerow intercropping and trees on croplands) and sequential (e.g., planted tree fallows) agroforestry systems.

In hedgerow intercropping (HI), the hedge/crop interactions are dominated by soil fertility improvement and competition for growth resources. Higher crop yields in HI than in sole cropping are noted mostly in inherently fertile soils in humid and subhumid tropics, and are caused by large fertility improvement relative to the effects of competition. But, yield increases are rare in semiarid tropics and infertile acid soils because fertility improvement does not offset the large competitive effect of hedgerows with crops for water and/or nutrients. Whereas improved soil fertility and microclimate positively influence crop yields underneath the canopies of scattered trees in semiarid climates, intense shading caused by large, evergreen trees negatively affects the yields. Trees in boundary plantings compete with crops for above- and belowground resources, with belowground competition of trees often extending beyond their crown areas. The major biophysical interactions in improved planted fallows are improvement of soil nitrogen status and reduction of weeds in the fallow phase, and increased crop yields in the subsequent cropping phase. In such systems, the negative effects of competition and microclimate modification are avoided in the absence of direct tree-crop interactions.

Future research on biophysical interactions should concentrate on (1) exploiting the diversity that exists within and between species of trees, (2) determining interactions between systems at different spatial (farm and landscape) and temporal scales, (3) improving understanding of belowground interactions, (4) assessing the environmental implications of agroforestry, particularly in the humid tropics, and (5) devising management schedules for agroforestry components in order to maximize benefits.
\end{abstract}

\section{Introduction}

Exploitation of interactions between woody and nonwoody (herbaceous or annual crop) components is the key to the success of all agroforestry (AF) systems. Therefore, a better understanding of the interactions provides a strong

* Florida Agricultural Experiment Station Journal Series No. R-06063. 
for improvement of traditional, as well as evolving, systems. Research on interactions in AF systems, which was of a relatively low-key nature until the early 1990s, is now receiving increasing attention. Anderson and Sinclair (1993) and Nair et al. (1994) examined the topic from an ecological perspective, whereas various chapters in the recent book on tree-crop interactions (Ong and Huxley, 1996) approached it from a more quantitative and physiological perspective. Additionally, other recent reviews have examined specific aspects of interactions, e.g., pest and disease relations in agroforestry (Singh Rathore, 1995). Interactions in shade-tree/perennial-crop systems and mixed-tree systems have been discussed separately in this volume by Beer et al. (1997) and Khanna (1997), respectively. Thus, considerable progress has been made lately in our understanding of biophysical interactions in AF systems. But, so far, the efforts have been confined mostly to strategic research, with little or no progress in translating this knowledge into management options. The emphasis in this paper, therefore, is to synthesize the available information and discuss the agronomic significance of biophysical interactions in the major agroforestry systems, focusing on systems not covered by other reviewers in this volume. By following this approach, the paper complements the efforts of Sanchez (1995) and stresses the importance of management implications.

In the study of biophysical interactions in $\mathrm{AF}$, some efforts were made to extrapolate from research on annual intercropping, on the assumption that the principles of interactions between component species for growth resources are common in all types of plant associations. Thus, early research (during the 1980s) on resource 'capture' in agroforestry systems concentrated on the interception and use of radiation, although radiation is seldom the most limiting growth resource in the tropics (Ong and Black, 1994). Agroforestry systems are much more complex than annual intercropping systems because there are major differences in the nature and arrangement of components and, therefore, in the nature and extent of interactions. Of considerable importance is the fact that the components in AF systems are 'unequal,' the trees being dominant and perennial. Thus, interactions in AF systems are continuous, rather than seasonal as in annual systems, and the course and extent of interactions are largely determined by the system's tree component.

Interaction is defined as the effect of one component of a system on the performance of another component and/or the overall system (Nair, 1993). Furthermore, for this review, AF systems are broadly categorized into two groups: 1) simultaneous systems, in which trees and crops are grown together in different spatial arrangements; examples include trees on croplands, hedgerow intercropping (HI), intercropping in perennial-tree-crop stands and multistrata systems; and, 2) sequential systems, in which trees and crops are grown in rotation; examples include rotational bush fallow or planted tree fallows followed by crops (Sanchez, 1995). Some systems, such as taungya, rotational HI, and relay planted tree fallows in crops combine the features of both simultaneous and sequential systems. 
Table 1. Major tree-soil-crop interaction processes in tropical agroforestry systems.

\begin{tabular}{|c|c|}
\hline Nature of interaction & Process \\
\hline \multicolumn{2}{|l|}{ Soil fertility: chemical } \\
\hline Carbon & $\begin{array}{l}\text { - Increases in active pools of SOM through litterfall, root turnover } \\
\text { and incorporation of tree prunings and crop residues }\end{array}$ \\
\hline Nitrogen & $\begin{array}{l}\text { Increased soil N supply through } \\
\text { - Nitrogen fixation } \\
\text { - Deep soil N capture } \\
\text { - Reduced leaching }\end{array}$ \\
\hline Phosphorus & $\begin{array}{l}\text { - Transformation of less available inorganic } \mathrm{P} \text { forms into readily } \\
\text { plant-available forms }\end{array}$ \\
\hline Cations $(\mathrm{Ca}, \mathrm{Mg}, \mathrm{K})$ & - Relocation in soil profile \\
\hline Aluminum & $\begin{array}{l}\text { - Organic acids binding } \mathrm{Al} \\
\text { - Localized Al detoxification }\end{array}$ \\
\hline Soil fertility: physical & $\begin{array}{l}\text { - Improved soil aggregation, porosity and pore connectivity } \\
\text { - Reduced soil bulk density } \\
\text { - Break up of hardpans/compacted soil layers }\end{array}$ \\
\hline Soil fertility: biological & $\begin{array}{l}\text { - Build up of soil macrofauna and microbial populations } \\
\text { - Build up of VAM and rhizobial populations } \\
\text { - Reduced/increased soil insect pests and pathogens }\end{array}$ \\
\hline Competition & $\begin{array}{l}\text { - Sharing of growth resources: light, water and nutrients by trees } \\
\text { and crops }\end{array}$ \\
\hline Microclimate & $\begin{array}{l}\text { - Shading: reduced soil and air temperature } \\
\text { - Shelter: protection from wind } \\
\text { - Rainfall interception and re-distribution }\end{array}$ \\
\hline Conservation & $\begin{array}{l}\text { - Reduced soil erosion } \\
\text { - Reduced leaching }\end{array}$ \\
\hline $\begin{array}{l}\text { Biological: } \\
\text { Weeds }\end{array}$ & $\begin{array}{l}\text { - Reduced weed populations } \\
\text { - Shifts in weed species } \\
\text { - Decreased viability of perennial weed rhizomes } \\
\text { - Decay of annual weed seed bank }\end{array}$ \\
\hline Pests and diseases & - Reduced/increased pest-parasite/predator populations \\
\hline Allelopathy & - Release of growth affecting chemicals into soil environment \\
\hline
\end{tabular}

The study of interactions in agroforestry requires the examination of a number of complex processes (Table 1). However, it can be simplified if the interactions are categorized according to the factors that are most affected (Akyeampong et al., 1995a). These relate to soil fertility (F) [which includes soil chemical ( $\mathrm{Sc}$ ), soil physical ( $\mathrm{Sp}$ ) and soil biological ( $\mathrm{Sb}$ ) interactions], competition $(\mathrm{C})$ [which includes competitive interactions for soil water $(\mathrm{Sw})$, soil nutrients $(\mathrm{Sn})$ and radiation $(\mathrm{r})]$, microclimate $(\mathrm{M})$, pests and diseases $(\mathrm{P})$ [which include interactions related to weeds $(\mathrm{Pp})$, insects $(\mathrm{Pi})$ and diseases $(\mathrm{Pd})]$, soil conservation (L) and allelopathy (A). 
In general terms, the interaction effect (I) on crop yields in the two major groups of AF systems can be expressed as follows:

simultaneous systems: $\mathrm{I}=\mathrm{F}+\mathrm{C}+\mathrm{M}+\mathrm{P}+\mathrm{L}+\mathrm{A}$; and

sequential systems: $\mathrm{I}=\mathrm{F}+\mathrm{M}+\mathrm{P}+\mathrm{L}+\mathrm{A}$.

[F includes Sc, Sp, and Sb; C includes Sw, Sn, and r; P includes Pp, Pi and Pd].

An important difference between these two groups of systems is the absence of (C) in sequential systems, where interactions between trees and crops are indirect, rather than direct as in simultaneous systems. The resource competition that occurs among tree species and between trees and weeds during the fallow period will have no direct effect on subsequent crops. The effect of (M) in sequential systems occurs mostly in slash-and-mulch systems rather than in slash-and-burn systems. On small farms, the distinction between simultaneous and sequential systems may lose its meaning as spatial interactions and boundary effects will occur in fine-grained mosaics.

It needs to be emphasized that many of the interactions are interdependent; for example, soil chemical, physical and biological changes are closely associated with organic inputs. Therefore, interaction effects for these variables cannot be experimentally estimated independent of one another. Some factors may be interdependent over time; for example, part of the (C) effect in a season may be the basis for the (F) effect in the following season (Cannell et al., 1996). Nevertheless, studying the interactions in a factor-wise framework will help us determine the relative importance of each factor for any given system, and subsequently enable us to focus on the more important factors. Moreover, quantifying the magnitude of interactions over a range of species, soil, management, and climatic conditions will help determine the biophysical limits of the system.

With this background, we review and discuss biophysical interactions in simultaneous and sequential AF systems. Within the former category, systems with contrasting methods of tree management are considered, for example, hedgerow intercropping, which manages trees as hedges, and trees on croplands, which allows trees to grow normally. The review draws heavily on the results of research in sub-Saharan Africa because, compared with tropical Asia and Latin America, this region has contributed substantially more to agroforestry research and publication of results in international media.

\section{Simultaneous systems}

\section{Hedgerow intercropping}

In tropical agroforestry, hedgerow intercropping (HI) is synonymous with alley cropping, and involves the growing of crops between hedgerows of regularly coppiced woody species. The term HI is preferred in this paper to distinguish 
this technology from the growing of arable crops in alleys formed by widely spaced rows of uncoppiced trees, a practice that is increasingly referred to as alley cropping in temperate agroforestry. HI was promoted initially (in the 1980s) for improving soil fertility and sustainability of crop production on nutrient-depleted soils in the humid and subhumid tropics, where bush fallowing had been traditionally practiced for the purpose. However, HI became attractive to researchers and development organizations in other parts of the tropics because it combined the benefits of tree fallow and continuous cropping. The technology was then extended to fodder production systems (by using fodder species as hedgerows) and to erosion control efforts on sloping lands (by using contour-aligned hedgerows as live barriers). The potential of HI for these different purposes has been investigated under several agroclimatic conditions and the results have been reviewed by many authors (Kang et al., 1990; Nair, 1990; Kang, 1993; Akyeampong et al., 1995a; Sanchez, 1995; Cooper et al., 1996).

As a simultaneous AF system, all previously mentioned categories of tree-crop interactions occur in HI (Akyeampong et al., 1995a). However, the major interactions that affect crop yields are related to soil fertility, competition, weed control, and soil conservation particularly on sloping lands (Table 2 ). Hedgerows might increase the yield of the closest crop rows on the sheltered side (Monteith et al., 1991; Huxley et al., 1994), and hedgerow prunings might reduce soil evaporation, if applied as mulch (Tian et al., 1993). However, microclimate changes that result from hedgerows pruned regularly at optimum height have a small overall effect on crop yield, relative to other factors (Monteith et al., 1991; Ong et al., 1991). Barrier hedgerows have been shown to control soil erosion and surface loss of nutrients (Lal, 1989b; Kiepe and Rao, 1994). Compared to traditional soil conservation technologies, HI systems have been found to increase crop yields in a shorter period

Table 2. Net effect on crop yield of tree-soil-crop interactions in hedgerow intercropping systems in different climates, assuming a moderately a fertile soil.

\begin{tabular}{|c|c|c|c|}
\hline Process & Semiarid & Subhumid & Humid \\
\hline $\begin{array}{l}\text { Nutrient availability to } \\
\text { alleycrops }\end{array}$ & positive $(\mathrm{S} \rightarrow \mathrm{L})$ & positive (L) & positive (L) \\
\hline Soil chemical changes & positive (S) & positive (S) & positive (L) \\
\hline Soil physical changes & positive $(\mathrm{S} \rightarrow \mathrm{L})$ & positive $(\mathrm{S} \rightarrow \mathrm{L})$ & positive $(\mathrm{S} \rightarrow \mathrm{L})$ \\
\hline Soil biological changes & neutral & positive $(\mathrm{S} \rightarrow \mathrm{L})$ & positive (L) \\
\hline Soil conservation & positive $(\mathrm{S} \rightarrow \mathrm{L})$ & positive (L) & positive (L) \\
\hline Water availability to alleycrops & negative (L) & neutral/negative (S) & neutral \\
\hline Shading & neutral & negative (S) & negative (L) \\
\hline Microclimate changes & positive $(\mathrm{S}) /$ neutral & neutral & neutral \\
\hline Weed suppression & positive $(\mathrm{S})$ & positive (L) & positive (L) \\
\hline Crop yield & negative $(S \rightarrow L)$ & positive $(\mathrm{S} \rightarrow \mathrm{L})$ & positive $(\mathrm{S} \rightarrow \mathrm{L})$ \\
\hline
\end{tabular}

$\mathrm{S}=$ small; $\mathrm{L}=$ large 
of time (Banda et al., 1994). Soil conservation effects of hedgerow systems are discussed further in this volume by Craswell (1997). The various mechanisms of tree-soil-crop interactions in HI with respect to soil fertility, competition and weed control are reviewed in the subsequent sections.

\section{Soil fertility: chemical}

Hedgerows exercise short- and long-term effects on alley-planted crops. The short-term effects, which influence current-season crops, are governed by the nutrients released through mineralization of recently added hedgerow prunings and root decay. The long-term effects, which influence the sustainable production of crops, are governed by changes in soil nutrient stocks that occur over the years from regular additions of prunings and root turnover. In any given season, only a relatively small proportion (10\% to $20 \%)$ of $\mathrm{N}$ in prunings may be taken up by the alleycrop (Mulongoy and van der Meersch, 1988; Xu et al., 1993a; Akinnifesi et al., 1997; D.N. Mugendi, pers. comm., 1997); a substantial part of the $\mathrm{N}$ is leached from the soil-plant system and the rest is humified in the soil (Xu et al., 1993b). The unutilized $\mathrm{N}$ from prunings will contribute to the build up of soil $\mathrm{N}$ 'capital.'

The chemical aspects of soil fertility have received much emphasis in the research on HI. Major benefits of regular additions of hedgerow prunings to soils are increases in the dynamic pools of soil organic matter (SOM) and plant-available soil nutrients. The magnitude of changes depends on the amount and quality of prunings applied, soil type, system management, climate, and duration of the practice of the system. In general, significant improvement in soil nutrient status under $\mathrm{HI}$ has been observed in inherently good soils in subhumid and humid tropics, such as Oxic Paleustalfs in Nigeria (Lal, 1989c; Kang et al., 1990), and a loamy clay Tropofluvent in Peru (Salazar et al., 1993). On the other hand, soil nutrient status under HI has either declined - as occurs in annual cropping systems - in acid infertile soils of the humid tropics, for example, Typic Paleudults in Peru (Szott et al., 1991), or has remained relatively unaffected, even on good soils, in the semiarid tropics (Mathuva et al., 1997). Absence of any positive soil chemical changes in these environments is attributable to the small quantity of prunings produced by the hedgerows.

Hedgerow species have also showed significant differences in ability to influence soil chemical properties. In Nigeria, Kang (1993) observed the relative ranking of species for soil surface organic $\mathrm{C}$ as a function of litter quantity and quality, after five years of alleycropping, as follows: leucaena (Leucaena leucocephala) > gliricidia (Gliricidia sepium) > alchornea (Alchornea cordifolia) $>$ dactyladenia (Dactyladenia barteri). Yamoah et al. (1986b) ranked the three species they compared for improving a number of soil chemical properties as Senna siamea $>$ gliricidia > flemingia (Flemingia macrophylla). In Rwanda, calliandra (Calliandra calothyrsus) showed the maximum positive impact on soil fertility, followed by Senna spectabilis, Leucaena diversifolia and leucaena; differences were largely related to the 
amount of tree biomass produced (Balasubramanian and Sekayange, 1991). Species differences were due primarily to differences in their adaptation to soil and climatic conditions, rooting characteristics, biological $\mathrm{N}_{2}$ fixation (BNF), and ability to establish mycorrhizal associations.

The major mechanisms by which hedgerows increase or maintain nutrient status in the crop rooting zone are: (1) nitrogen input into the system through $\mathrm{BNF}$ in the case of $\mathrm{N}_{2}$-fixing species (Dommergues, 1995), (2) reduced soil erosion, (3) reduced leaching of nutrients (Hauser and Kang, 1993), and (4) uptake of soil nutrients from deep soil layers that are beyond the crop root zone and recycling them to the soil surface via prunings. Although hedgerow systems do not increase total soil $\mathrm{P}$, they have been found to increase plant available P (Haggar et al., 1991; Hands et al., 1995). External sources of P are essential on P-deficient soils to sustain the productivity of HI (Palm, 1995). Nutrient cycling through aboveground prunings is many times higher than that which occurs through root turnover (Schroth and Zech, 1995; Govindarajan et al., 1996).

\section{Soil fertility: physical}

Hedgerow intercropping, as compared with annual crops, has considerably improved soil physical properties. These improvements include better soil aggregation (Yamoah et al., 1986b; Mapa and Gunasena, 1995), lower bulk density (Yamoah et al., 1986b; Lal, 1989d; Hulugalle and Kang, 1990; Dalland et al., 1993; Jama et al., 1995; Mapa and Gunasena, 1995; Alegre and Rao, 1996), lower resistance to penetration (Lal, 1989d; Dalland et al., 1993), reduced surface sealing (Hulugalle and Ndi, 1993) and improved soil porosity (Lal, 1989d; Hulugalle and Kang, 1990; Dalland et al., 1993). The consequences of these changes are increased water infiltration (Lal, 1989e; Halugalle and Kang, 1990; Hulugalle and Ndi, 1993; Mapa and Gunasena, 1995), higher saturated hydraulic conductivity (Jama et al., 1995; Alegre and Rao, 1996), and higher water holding capacity (Yamoah et al., 1986b; Lal, 1989e) under HI, as compared with crop-only controls, in a range of climatic and soil conditions. The improved soil physical conditions under HI are primarily due to increased SOM and root activity of perennial hedgerows, and secondarily to increased soil biological activity by soil macrofauna. It is doubtful that improved soil physical conditions will increase available soil water to alleycrops in water-limiting situations because of the dominance of hedgerows over crops.

\section{Soil fertility: biological}

Soil biological activity, mediated through soil fauna and flora, is crucial in low-input systems because, in these systems, nutrient supply to plant growth is largely due to the decomposition of newly added organic residues and mineralization of SOM. Yamoah et al. (1986b) observed 46\% higher soil microbial biomass $\mathrm{C}$ (a measure of biological activity) under HI with gliri- 
cidia and Senna sp. than under sole cropping, in the $0-15 \mathrm{~cm}$ soil layer. More earthworm activity was reported under HI than under annual cropping in a number of trials on Alfisols in Nigeria (Kang et al., 1990; Hauser, 1993). In a seven-year trial, there were nearly five times more worm casts under leucaena hedgerows $\left(117 \mathrm{Mg} \mathrm{ha}^{-1}\right)$ than in the middle of the alley $\left(24 \mathrm{Mg} \mathrm{ha}^{-1}\right)$ or in sole maize (Zea mays) (28 $\left.\mathrm{Mg} \mathrm{ha}^{-1}\right)$ (Hauser, 1993). Under HI, worm casts recycled three times more $\mathrm{N}, \mathrm{K}$ and $\mathrm{Mg}$ to the surface, as compared with sole maize. Hedgerow species (e.g., dactyladenia and gliricidia) that maintained higher shade and water near the soil surface increased earthworm activity more than other tree species (Kang et al., 1994). Similarly, higher populations of earthworms, ants and termites were noted under HI with gliricidia and erythrina (Erythrina poeppigiana) in Costa Rica (Hands et al., 1995). Soil macrofauna (especially earthworms) will play a significant role in improving soil structure and, in turn, soil water relations and nutrient availability to crops.

\section{Competition for growth resources}

Competition for growth resources is inevitable between hedgerows and crops, but its importance is determined by climate, management, soils, and hedgerow and crop species. In humid and subhumid environments, where adequate rainfall favors rapid tree growth, competition is primarily for light, resulting in significant negative effects (crop shading) on the intercrops (Lawson and Kang, 1990). The relative importance of various hedge/crop interactions to crop yields in humid tropics is illustrated by the results of an ongoing longterm experiment at Lampung, Indonesia (av. rainfall $2200 \mathrm{~mm} \mathrm{yr}^{-1}$ ) for three contrasting tree species - gliricidia, leucaena, and peltophorum (Peltophorum dasyrrachis). The interaction effects considered were: (1) soil fertility (F), which was partitioned into the cumulative long-term effect of soil chemical, physical and biological changes (determined by removing hedgerows eight years after their establishment) and short-term effect primarily due to current addition of mulch (determined by transferring to sole maize an equivalent amount of mulch produced by hedgerows in HI), and (2) competition (C), which was partitioned into competition for light (or shade effect) and belowground resources (determined with/without root barriers). Effects due to mulch and root interactions were small for all three species (Figure 1). Both the fast-growing leucaena and the open-canopy gliricidia provided large positive fertility effects and negative shade effects. Peltophorum - a slow-growing, non- $\mathrm{N}_{2}$-fixing species, with a compact canopy - also exhibited a substantial positive fertility effect, but contrary to the other species, showed only a small negative effect due to shade. The combined result of the different interactions on intercropped maize yield was negative for leucaena and gliricidia because the positive fertility effect was offset by the negative shade effect; only peltophorum, which showed the lowest shade effect, resulted in a net positive effect on maize (ICRAF, 1995). The study questions fast growth and $\mathrm{N}_{2}$ fixation as criteria for selection of species for HI, and suggests that species 


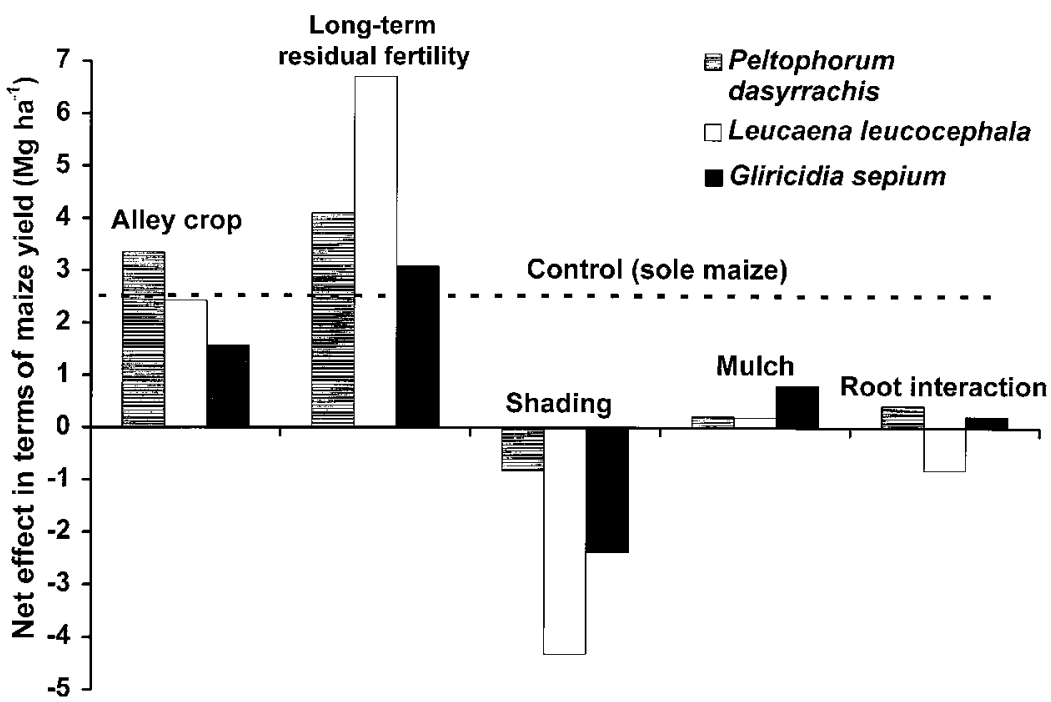

Fig. 1. Net effects, expressed in increase or decrease of maize grain yield, of long-term residual soil fertility (estimated by removing hedgerows), short-term mulch (estimated in terms of response of sole maize to equivalent amount of prunings produced by hedgerows), root interactions (estimated from yields with and without root pruning) and shading (estimated by difference) in an eight-year-old hedgerow intercropping system with three contrasting tree species in North Lampung, Indonesia. The results are based on yields from the 1994 first rainy season, with the above treatments applied eight years after the establishment of the trial. The alleycrop yield is assumed to reflect the net result of various hedge-crop interaction effects. (Source: ICRAF, 1995).

that supply high $\mathrm{N}$ per unit shade (such as peltophorum) are appropriate for the humid tropics (van Noordwijk et al., 1995).

The shade of hedgerows may have no effect or beneficial effect on shadetolerant and short-duration crops (e.g., beans: Phaseolus sp.), while it may generally have negative effect on other short-statured and longer-duration crops (e.g., rice: Oryza sativa). The negative effect could be more pronounced if hedgerows are spaced closely and their pruning is delayed. In the humid tropics, an alley spacing wider than the $4 \mathrm{~m}$ that is commonly used elsewhere would be appropriate. Based on simulation studies combining the effects of light interception and $\mathrm{N}$ supply from erythrina prunings in Costa Rica, Nygren and Jiménez (1993) recommended for optimum alleycrop yields a betweenrow spacing of 6 or $8 \mathrm{~m}$, a within-row spacing of 1 or $2 \mathrm{~m}$, and an east-west orientation of rows.

Belowground competition for nutrients appears to be the major factor affecting the performance of $\mathrm{HI}$ in acid infertile soils of the humid tropics. On a Typic Paleudult in Yurimaguas, Peru, hedgerows of inga (Inga edulis) reduced the yield of rice in rows closest to the hedgerows by up to $50 \%$ by one year; root pruning of hedgerows at $25 \mathrm{~cm}$ from the hedgerow base, to $20-\mathrm{cm}$ soil depth, significantly increased the rice yield by $20 \%$, compared to 
yields from alleys without root pruning (Fernandes et al., 1993). On alluvial soils at the same location, crop-yield reductions were noted up to $1.5 \mathrm{~m}$ from hedgerows, for three different tree species. Input of additional mulch compensated for the reduced yields to a large extent (Salazar et al., 1993). Competition for nutrients was reported as the reason for yield reductions because the site received high rainfall $\left(2200 \mathrm{~mm} \mathrm{yr}^{-1}\right)$ and hedges were pruned periodically to 0.65 to $0.75 \mathrm{~m}$ height, suggesting little or no competition for water or light. Such a high degree of belowground competition in acid soils could be attributed to the concentration of tree roots in same soil layer $(0-20$ $\mathrm{cm}$ ) as crop roots. This was confirmed by root observations on inga in Peru (Fernandes et al., 1993) and on A. cordifolia, S. siamea and Gmelina arborea in Nigeria (Ruhigwa et al., 1992). Species such as D. barteri and peltophorum that root deeper, below the crop root zone, appear to be better suited to acid soils (Ruhigwa et al., 1992; van Noordwijk et al., 1995).

In the semiarid tropics, the competition of hedgerows with crops is primarily for water. On Alfisols near Hyderabad, India, with 600 to $700 \mathrm{~mm}$ of rainfall during the main cropping season, yields of a number of crops in HI with leucaena were severely reduced (up to 90\%) compared with the crop-only control. Installation of a root barrier, up to $0.5-\mathrm{m}$ depth, between leucaena hedges and crop rows removed the effect of belowground competition and restored crop yields almost to the level in sole cropping (Singh et al., 1989; Rao et al., 1990; Ong et al., 1991; Rao et al., 1991a).

Detailed measurements of soil water in the $165-\mathrm{cm}$ soil profile during three consecutive seasons under HI with contrasting Senna species (S. siamea and S. spectabilis) and a maize-cowpea (Vigna unguiculata) annual crop system at Machakos, Kenya (av. rainfall $760 \mathrm{~mm} \mathrm{yr}^{-1}$ in two rainy seasons), highlighted the importance of competition of hedgerows for water in semiarid environments (Figure 2). Soil water under both HI systems was lower than in the annual crop system throughout the study period and the differences were greater in periods of water stress. Soil water depletion was greater under the fast-growing and high-biomass-producing $S$. spectabilis than under the slowergrowing and less-biomass-producing $S$. siamea. The soil profile was never fully recharged, even when rainfall was $547 \mathrm{~mm}$ (50\% higher than normal) during the 'short rainy' season of 1994-95, because of severe water depletion in the previous season. This points out that interseasonal water deficits in HI can contribute to water shortage for crops in any given season. Similar observations were made in other trials conducted in Machakos, Kenya (Govindarajan et al., 1996; McIntyre et al., 1997). Root studies revealed the lack of spatial complementarity between the tree and crop components in water use, as a large percentage of fine roots of many hedgerow species were in the top $0.5 \mathrm{~m}$ soil layer where crop roots were also concentrated (Rao et al., 1993; ICRAF, 1996).

Light competition was negligible in the above studies in semiarid India and Kenya because hedgerows were pruned to $0.5 \mathrm{~m}$ or $0.75 \mathrm{~m}$ twice per season, and yields of crop rows closest to hedges were similar to those in the 


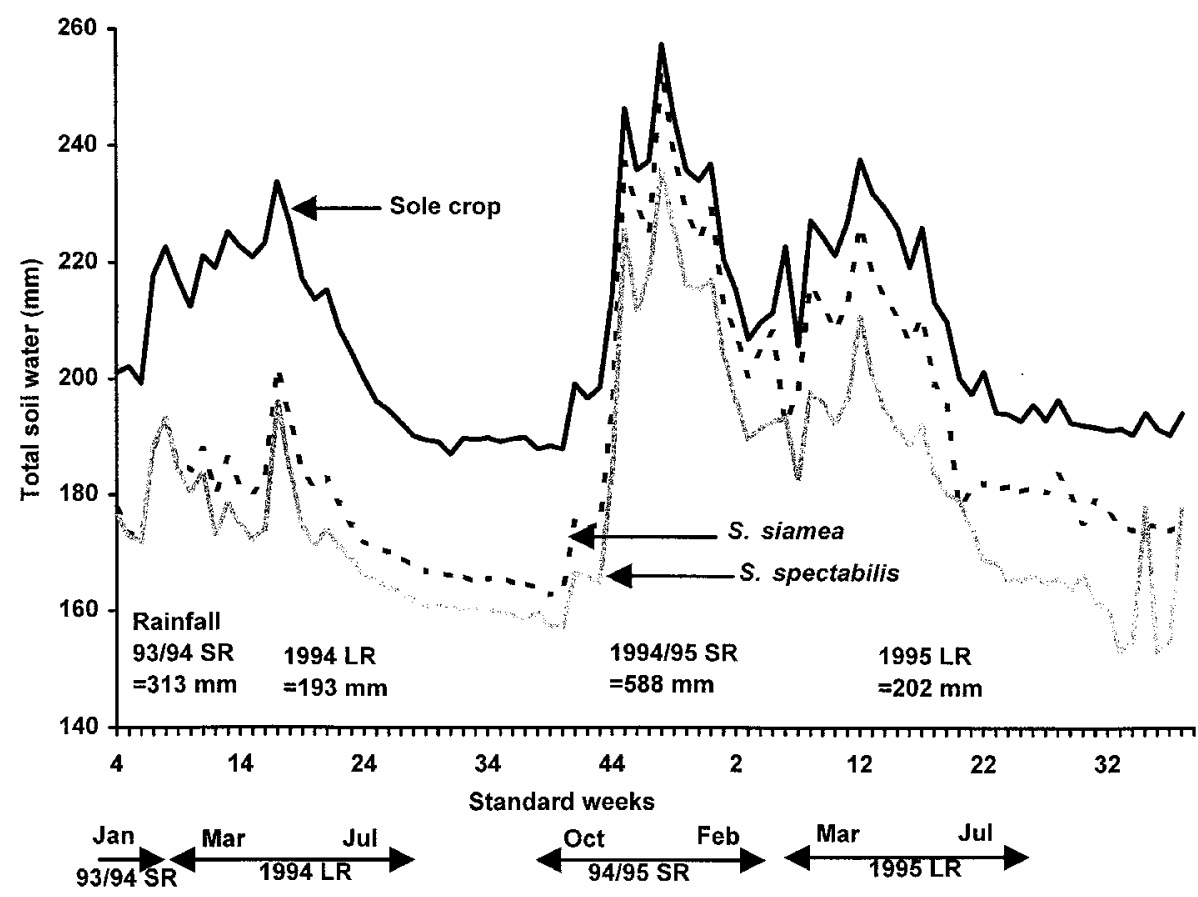

$\mathrm{LR}=$ long rainy season; $\mathrm{SR}=$ short rainy season

Fig. 2. Weekly changes in the total soil water content in $165-\mathrm{cm}$ profile under hedgerow intercropping with Senna siamea and S. spectabilis, and sole annual crop (maize-cowpea (Vigna unguiculata) sequential) system during three cropping seasons (January 1994 to November 1995) (Source: H. Odhiambo and C. K. Ong, unpublished).

center of the alleys (Rao et al., 1990; Ong et al., 1991; Jama et al., 1995; Govindarajan et al., 1996). Substantial reduction of crop yields even when crops were fertilized at recommended rates confirms that the inadequacy of water to meet the demands of hedgerows and crops is the principal factor determining crop yields in HI in semiarid climates (Rao et al., 1991b; Jama et al., 1995).

\section{Weed control}

One of the major effects of trees in HI is reduction of weeds compared with annual cropping. This reduction is probably due to the complementary processes of: (1) mulch from hedgerow prunings providing a ground cover (Yamoah et al., 1986a; Kang, 1993); (2) hedgerows shading the alleys (Yamoah et al., 1986a; Jama et al., 1991) and competing with weeds for other growth resources (Rippin et al., 1994); and (3) potential allelopathy from hedgerow species (Obondo, 1987; Weston, 1996).

Striking differences were observed among hedgerow species in their ability 
to control weeds because species differ in biomass production and decomposition rates, and canopy spread. Species with slowly decomposing biomass, such as inga, achieved greater weed control than leucaena or erythrina in Peru (Salazar et al., 1993). Similarly, S. siamea controlled weeds better than gliricidia and flemingia in Nigeria (Yamoah et al., 1986a). In regard to weed control, the relative importance of competition and mulching effects depends on tree species. Rippin et al. (1994) reported that competition of gliricidia hedgerows accounted for all of the $28 \%$ reduction in weed growth in these plots because rapid decomposition prevented any effect of gliricidia mulch. In erythrina plots, competition accounted for a $13 \%$ reduction in weed growth and mulch accounted for $39 \%$. The potential for HI to control weeds is high in humid and subhumid environments where the climatic conditions favor weed growth (Kang, 1993; Rippin et al., 1994), and when prunings are used as mulch. Another significant process that occurs in HI - as a result of hedgerow shading and mulch - is a shift over time in the composition of weed species from difficult-to-control grasses and sedges to easily controllable broad-leaved weeds (Jama et al., 1991; Siaw et al., 1991). It is likely that, over years, HI might reduce the weed seed-bank in the soil, especially if the prunings are used as mulch, which would smother weeds, prevent further addition of weed seeds, and reduce seed viability by preventing germination. HI can also control perennial weeds, which are less dependent on the soil seed-bank, as indicated by the observations in long-term trials in southwestern Nigeria, where HI with gliricidia and leucaena reduced Imperata infestation by shading and probably allelopathy (Kang, 1993).

Allowing hedgerows to grow between cropping seasons will increase their potential to shade and smother weeds in the alleys. Three months of uninterrupted growth of leucaena hedgerows, between the two cropping seasons, reduced weed growth by $93 \%$ at the subhumid coast of Kenya (Jama et al., 1991). However, long growth periods could lead to the potential danger of the tree species becoming a 'weed,' especially in the case of profusely seeding species such as leucaena and flemingia. The closer the hedgerows are spaced, the greater would be the potential for weed control (Jama et al., 1991), but close spacing also means loss of space for crops and greater competition of hedgerows with crops. Therefore, when determining the optimum spacing of hedgerows, the primary objective should be the improvement of crop yields. The negative effects of competition versus the positive effects of biomass production for nutrients should be the main considerations, with weed control assuming lesser importance.

\section{Effect on crop yields}

The effect of HI on crop yields could be positive or negative depending on climate and soil conditions. Most studies have evaluated the system based on short-term results (two to three years) and a high proportion of trials reported increased yields from HI (Young, 1997). However, early success or failure does not indicate the realistic long-term potential of the system, especially if 
the early seasons are characterized by atypical rainfall for the site. As the effects of trees are likely to be cumulative, they take a longer time to stabilize. Additionally, many experiments have suffered from the disadvantages of small plots, in which the sole crop yields could be underestimated because of insidious exploitation of water and nutrients by tree roots from HI plots. Akyeampong et al. (1995a) reviewed the results of 2 to 3-year-old experiments conducted by ICRAF in sub-Saharan Africa and observed no benefit of $\mathrm{HI}$ at sites (50\% of total sites) where rainfall was less than $1000 \mathrm{~mm} \mathrm{yr}^{-1}$, primarily because the negative effect of competition for water exceeded the positive effect of improved soil fertility. Woomer et al. (1995) reviewed the short-term results of a number of trials conducted on diverse soils, mostly in subhumid and humid West Africa. They observed, on average ( $n=44$ observations), $183 \%$ yield increase for maize in $\mathrm{HI}$ over sole crop control, but as these results were based on small plots, tree root interference with maize controls might have exaggerated the advantage of HI.

In order to assess the long-term performance of HI, we have reviewed the results of 29 trials, mostly with small plots, conducted for four or more years over a wide range of soils and climates. Experiments on sloping lands where the primary benefit is likely to be soil conservation are not included in this analysis. Twenty-eight of these trials evaluated the potential of HI without application of $\mathrm{N}$ fertilizer to crops, but the majority received $\mathrm{P}$ fertilizer; one trial evaluated the hedgerows for fodder production, with crop fertilization at the recommended rate (Rao et al., 1991b). When the trials involved multiple hedgerow species or different alley widths, results of the best HI system were considered. The average yields of annual crops from HI relative to those of the sole system are presented in Figure 3. Yields of sequential crops in bimodal rainfall sites are presented separately if crops involved are different (hence more than 29 observations in Figure 3). Tree species used in these trials were leucaena $(n=12)$, Senna siamea $(n=3)$, L. diversifolia $(n=1)$, gliricidia alone or mixed with calliandra $(n=2)$ and Albizia lebbeck $(n=1)$ in the semiarid and subhumid climates; and calliandra $(n=3)$, erythrina $(n=4)$, inga, peltophorum and Paraserianthes falcataria at one site each in the humid tropics.

The results showed both positive ( $n=15$ for cereals, $n=8$ for non-cereal crops such as beans, cowpea and cassava (Manihot esculenta)) and negative ( $n=13$ for cereal crops and $n=1$ for sweet potato (Ipomoea batatas) and taro (Colocasia esculenta)) effects of $\mathrm{HI}$ on crop yields across the tropics, indicating that the system performance is location specific and sensitive to management, and that generalizations are difficult to make. Ignoring $<15 \%$ yield increases as unattractive to farmers, we find that only two of ten studies in semiarid sites $(<1000 \mathrm{~mm}$ rainfall) gave substantial yield increases. One of the sites with yield increases was a highland area in Rwanda with bimodal rainfall, where typical crop yields were very low (Balasubramanian and Sekayange, 1991); at the other site, soil and hedgerow management were very good (Bunderson, 1992). In subhumid environments (rainfall between 1000 

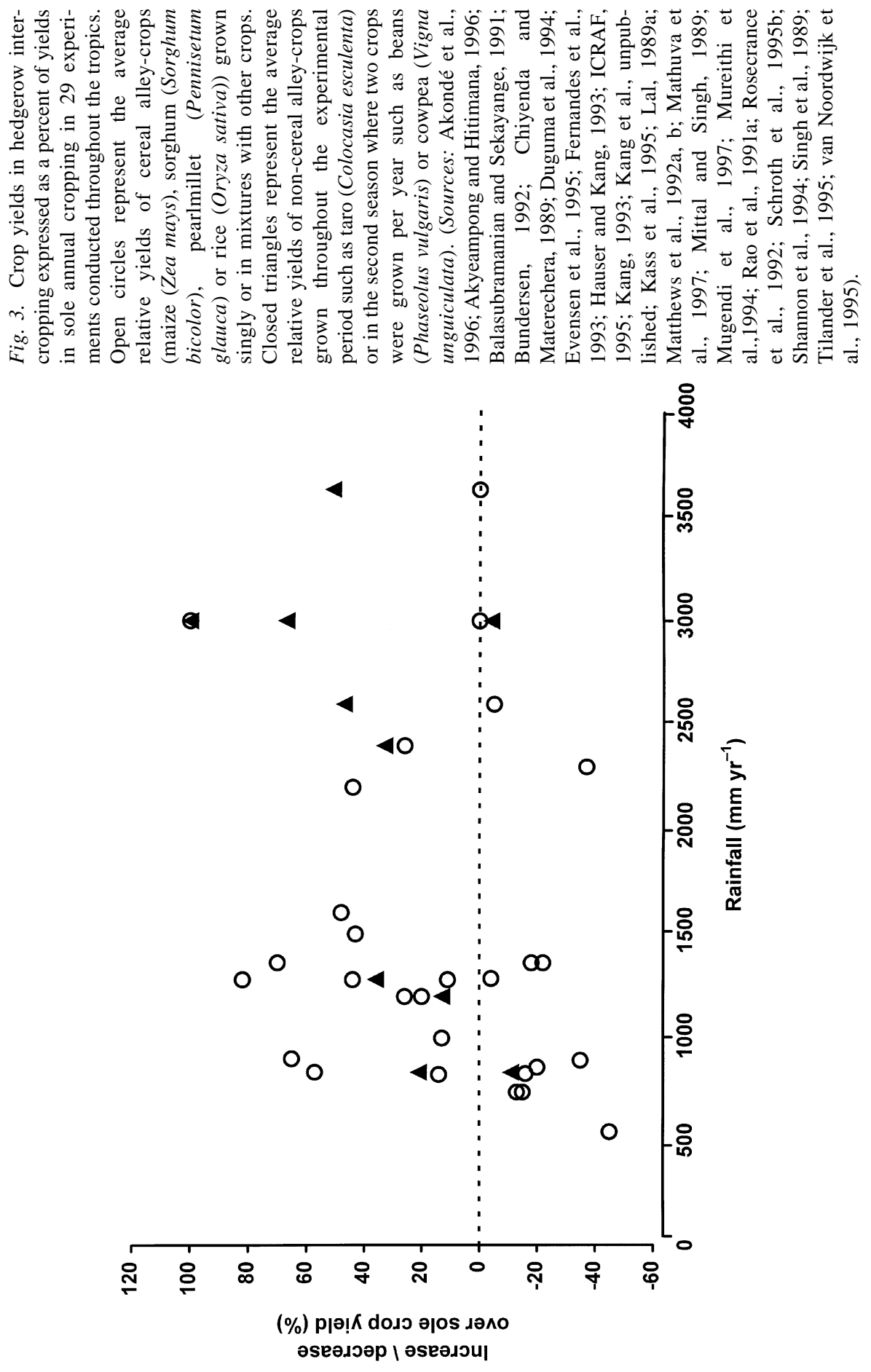
and $1600 \mathrm{~mm}$ ), significant positive yield responses were observed in seven out of eleven studies where the soils were either inherently fertile (Kang, 1993; Hauser and Kang, 1993; Mureithi et al., 1994; Shannon et al., 1994) or the acid infertile sites received external nutrients and lime (Akyeampong and Hitimana, 1996; Matthews et al., 1992a,b). In the humid tropics (rainfall > $2000 \mathrm{~mm}$ ), maize and taro did not benefit from $\mathrm{HI}$ in four out of eight trials, but interestingly bean and cowpea yields invariably increased.

Whereas low yield of hedgerow prunings ( 2 to $3 \mathrm{Mg} \mathrm{ha}^{-1} \mathrm{yr}^{-1}$ ) and competition of hedgerows for water were the major reasons for the negative results in water-limited areas (Ong et al., 1991; Rao et al., 1991a; Mathuva et al., 1997), low yield of prunings and competition of hedgerows for nutrients were responsible for negative results in poor soils (Matthews et al., 1992a, b; Fernandes et al., 1993). Inadequate water limited the response of crops even though HI improved soil fertility in certain sites of the semiarid tropics. In favorable environments, hedgerows produced 8 to $12 \mathrm{Mg} \mathrm{ha}^{-1} \mathrm{yr}^{-1}$ of prunings (dry weight) which increased SOM and ensured adequate supply of nutrients, especially N, to the alleycrops. However, to realize the benefits of HI, hedgerows must be frequently pruned to avoid shade competition (Kang, 1993). The reported increases of legume yields in HI is surprising, but may have occurred because these short-duration $\mathrm{C}_{3}$ crops do not suffer from shade competition, experienced a low incidence of pests and diseases, and benefited from improved microclimate.

In Peru, on Typic Paleudults characterized by high acidity and Al toxicity, annual crops did not produce economic yields beyond two or three years without applications of lime and fertilizer. On this site, HI maintained yields of Al-tolerant rice and cowpea crops at 1 and $0.5 \mathrm{Mg} \mathrm{ha}^{-1}$, respectively, for many seasons (ICRAF, 1995; Palm et al., 1995). Despite declining maize yields in sole-crop systems, HI produced higher yields over a long period in acid soils of Indonesia (van Noordwijk et al., 1995; ICRAF, 1995) and higher yields in the later years after one season fallow in acid soils of Burundi (Akyeampong and Hitimana, 1996). In both sites, rainfall was adequate, phosphorus was not limiting or was added through fertilizer, and 5 to $12 \mathrm{Mg}$ $\mathrm{ha}^{-1}$ of prunings were harvested per year. Reduced Al toxicity to maize, in addition to increased supply of nitrogen, could be responsible for the favorable response of $\mathrm{HI}$ in these situations. Many studies have indicated the reduction of $\mathrm{Al}$ toxicity with the addition of such a large amount of organic residues because their decomposition products would bind $\mathrm{Al}$ and reduce $\mathrm{Al}$ saturation (Wong et al., 1995).

\section{Conclusions}

Interactions related to soil fertility $(\mathrm{F})$ and competition for growth resources (C) dominate hedge/crop interactions in HI on lands with slopes of less than $15 \%$; the relative magnitude of interactions determines their net effect on crop yields. HI generally results in increased crop yields when $(F)$ is sufficiently large to overcome the negative effect of $(\mathrm{C})$. The advantages of $\mathrm{HI}$ are more 
common on relatively fertile, $\mathrm{N}$-deficient soils in subhumid and humid environments; in areas where hedgerows produce a large quantity of prunings; and where there is adequate water for both hedge and crop growth. In semiarid environments with inadequate water $\left(<1000 \mathrm{~mm}\right.$ rainfall $\left.\mathrm{yr}^{-1}\right)$ and on acid infertile soils, hedgerows produce too little biomass and/or become too competitive to benefit crops. If (C) is substantially reduced, HI may increase crop yields in some of these situations, even for a relatively small (F), but the necessary management of hedges could be too intensive to be practical. On acid soils, HI may give a positive response over the long term and with external inputs (lime and $\mathrm{P}$ fertilizer), but many small farmers may not cope with these requirements.

In agroclimates where $\mathrm{HI}$ is suitable, it can provide most of the $\mathrm{N}$ needed for moderate yields of cereals, but it will not supply adequate $\mathrm{N}$ or $\mathrm{P}$ to realize maximum yields. HI does not seem appropriate for tuber crops and cotton. Sustainable production from $\mathrm{HI}$ requires $\mathrm{P}$ fertilization and use of deep-rooted, $\mathrm{N}_{2}$-fixing trees. Leucaena and gliricidia are well suited for base-rich soils, whereas calliandra, Acacia auriculiformis, peltophorum, dactyladenia, erythrina, $L$. diversifolia and inga are suited for acid soils in specific climatic conditions.

\section{Trees in cropland systems}

Three distinct systems are considered under this category - scattered trees, boundary plantings, and intercropping with annual crops between widely spaced rows of trees. The degree of tree/crop interactions increases with increasing tree density, from low density in scattered tree systems to high density in tree/crop intercropping systems. Shade trees in perennial-crop systems, described by Beer et al. (1997) in this volume, are not considered here.

Scattered or dispersed trees in cropland, often known as 'parklands,' are a widespread traditional practice in the semiarid tropics (SAT). The best known systems are those involving faidherbia (Faidherbia albida), prevalent throughout the SAT of sub-Saharan Africa (CTFT, 1988; Laike, 1992; Saka et al., 1994); 'néré' (Parkia biglobosa), 'karité' (Vitellaria paradoxa) and neem (Azadirachta indica) in West Africa (Kater et al., 1992; Kessler, 1992; Vandenbeldt and Williams, 1992; Tilander et al., 1995); prosopis (Prosopis cineraria), neem and Acacia nilotica in India (Tejwani, 1994); and mango (Mangifera indica), melia (Melia volkensii), Acacia spp. and baobab (Adansonia digitata) in the semiarid parts of east and southern Africa. Nair $(1989 ; 1991)$ has documented many other systems of this type in the tropics. Trees in these systems are rarely planted but are derived from natural regeneration and are protected by farmers. Trees generally occur in low density, for example two to three trees ha ${ }^{-1}$ in the case of large trees such as néré (Kater et al., 1992), five to ten trees $\mathrm{ha}^{-1}$ in the case of karité (Kessler, 1992), 5-50 trees $\mathrm{ha}^{-1}$ in the case of faidherbia (Depommier et al., 1992), and 10-45 trees 
$\mathrm{ha}^{-1}$ in the case of prosopis (Tejwani, 1994). Farmers' objectives for maintaining trees in these systems are to provide products such as fodder, fruits, and fuelwood, and to reduce risk.

In contrast to trees in parklands, trees in boundary plantings and intercropping systems, practiced throughout the tropics, are deliberately planted and managed. Boundary plantings involve trees on farm and field boundaries, soil conservation structures and terrace risers. Intercropping systems use widely spaced rows of trees (rather than hedgerows), and include fast-growing trees such as Populus deltoides in northern India (Singh et al., 1993), and upperstory trees such as cedrela or cedro (Cedrela odorata) and grevillea (Grevillea robusta) in banana and bean fields in East Africa (Akyeampong et al., 1995b). The role of trees in these systems is mainly to provide poles, timber, fuelwood and/or fodder.

Three distinct tree/crop interaction zones can be distinguished in these systems: (1) a zone of light and root competition, mostly under the tree crown, (2) a zone of root competition, some area beyond the tree crown, and (3) open cropped areas that are relatively free from the interference of trees. The extent of the first two interaction zones depends on tree species, climate and soil, and spreads progressively over time with age and size of the tree. An understanding of these zones is essential for determining the optimum tree density and developing appropriate pruning regimes to maximize resource use and productivity of the systems. The major tree-soil-crop interactions that affect crop yields in these agroforestry systems are related mostly to chemical aspects of soil fertility, soil physical properties and water relations, and microclimate, especially shading (Table 3 ).

Table 3. Comparison of the effects of tree-soil-crop interactions under tree crowns and in open areas, in agroforestry systems with dispersed trees on cropland.

\begin{tabular}{ll}
\hline Parameter & Relative effect \\
\hline Soil organic matter & under crown $>$ open area \\
Soil N, P and cations & under crown $>$ open area \\
Soil pH & under crown $\geq$ open area \\
Mineralizable N & under crown $>$ open area \\
Soil particle size & under crown $\leq$ open area \\
Soil bulk density & under crown $<$ open area \\
Water infiltration & under crown $>$ open area \\
Light intensity & under crown $<$ open area \\
Soil temperature & under crown $<$ open area \\
Wind speed & under crown $<$ open area \\
Relative humidity & under crown $>$ open area \\
Soil evaporation & under crown $<$ open area \\
Microbial biomass & under crown $>$ open area \\
Crop yield & under crown $>$ open area \\
Crop yield & under crown $<$ open area \\
\hline
\end{tabular}


Soil fertility

Several studies have reported improved soil fertility in terms of SOM, extractable $\mathrm{P}$, and exchangeable cations under trees, compared with treeless open areas. These studies included a wide variety of trees, both $\mathrm{N}_{2}$-fixing species such as faidherbia (Kamara and Haque, 1992), prosopis (Aggarwal, 1980) and Acacia spp. (Belsky et al., 1993), and non- $\mathrm{N}_{2}$-fixing species such as néré and karité (Kater et al., 1992; Kessler, 1992; Tomlinson et al., 1995), and a number of other species (Campbell et al., 1994). The magnitude of reported changes under trees varied considerably. In four faidherbia parklands in Burkina Faso, the soils under trees had higher nutrient status than soils in open areas: $14 \%$ to $100 \%$ more organic C, $13 \%$ to $117 \%$ more organic N, $18 \%$ to $36 \%$ more extractable $\mathrm{P}, 2 \%$ to $67 \%$ more exchangeable $\mathrm{Ca}$, and $60 \%$ to $100 \%$ more exchangeable K (Depommier et al., 1992). The fertility improvement was mostly noted in the topsoil $(0-20 \mathrm{~cm})$. Generally, there was a fertility gradient with fertility decreasing from a tree's base to the edge of its crown or beyond. Higher SOM and organic forms of nutrients nearer the tree suggest that there could be increased mineralization and greater availability of plant available nutrients under trees than in the open areas during the cropping season (Rhoades, 1995).

Soil changes under trees may be species-specific and also dependent on size and age of the trees, and site conditions. For example, soils under leguminous trees such as Prosopis cineraria, Acacia tortilis and néré tended to be more acidic than soils under non-leguminous trees such as baobab and karité (Belsky et al., 1993; Kater et al., 1992). While both karité and néré trees significantly improved soil $\mathrm{C}$ and exchangeable $\mathrm{Mg}$ under their canopies, compared with open areas, only karité trees showed higher exchangeable Ca and $\mathrm{K}$ (Kater et al., 1992). The magnitude of changes in the soil properties under trees was generally greater in light soils than in heavy soils (Campbell et al., 1994) and in less fertile upland areas than in more fertile valley bottoms (Depommier et al., 1992).

Several mechanisms could be responsible for increased soil fertility under trees in parkland systems. Many leguminous trees contribute nitrogen to the system through BNF. Trees with deep roots can take up subsoil nutrients that are beyond the reach of crops and recycle them to the surface through litterfall (Buresh and Tian, 1997). Large trees, which are characteristic of parkland systems, often have extensive lateral root spread and so can take up nutrients from a large surrounding area and eventually concentrate them under their crowns. Néré trees, with crowns of 7-m radius, extended lateral roots up to $20 \mathrm{~m}$ from the tree base (Tomlinson et al., 1995). Lateral roots of Acacia seyal extended up to $26 \mathrm{~m}$ and those of Sclerocarya birrea extended up to $50 \mathrm{~m}$ (Groot and Soumaré, 1995). This process does not bring additional nutrients into the system but causes a redistribution of nutrients. Nevertheless, observations of improved soil fertility under trees, even after trenching has cut off surface lateral roots, prove the ability of tree processes, such as nutrient cycling and addition of litter, to improve soil fertility (Campbell et al., 1994). 
The excreta of livestock resting under the shade of trees during the dry season and of birds nesting in canopies could also contribute to higher nutrients under trees (Tejwani, 1994; Tomlinson et al., 1995). In environments that are subjected to wind erosion, such as the Sahel, tree canopies can intercept the fine particles of fertile topsoil carried by winds and deposit them under the canopies via stem flow and throughfall in the rainy season (Tomlinson et al., 1995). In addition to providing nutrients, this could be the major mechanism responsible for changes in soil texture under trees. Phosphorus accumulation under some agroforestry tree species is aided by their symbiotic association with endomycorrhizae which explore a large soil volume (Mason and Wilson, 1994; Tomlinson et al., 1995).

It has also been demonstrated that trees can improve soil physical conditions under their crowns, compared with open areas. Improvements are reflected through lower bulk density (Belsky et al., 1993), lower surface resistance to penetration (Campbell et al., 1994), increased porosity and greater aggregate stability. These changes would lead to higher rain water infiltration into the soil and higher availability of water to crops. Improvement in soil physical conditions is closely associated with increased SOM. Also, as old tree roots decay, they leave channels that increase water infiltration (van Noordwijk et al., 1991). However, the beneficial effects of improved soil physical conditions might be obliterated by compaction caused by animals sheltering under the trees during dry-season grazing.

It is possible that naturally regenerating trees in parkland systems establish and grow better in pre-existing islands of higher fertility (Geiger et al., 1994) and sites characterized by subterranean termite activity (Brouwer et al., 1992). In such circumstances, it is difficult to disprove the claim that trees are indicators of soil fertility rather than agents of soil improvement. Faidherbia trees apparently regenerate on fertile sites, but it is not known to what extent this is true of other tree species.

\section{Competition for growth resources}

Competition for light is unlikely to be a major factor under faidherbia because of its 'reverse phenology' of dropping leaves at the beginning of the rainy season (Vandenbeldt and Williams, 1992), nor under prosopis because of heavy lopping of foliage during the dry season for livestock feeding (Tejwani, 1994). However, shade could be a major problem under large, unmanaged, evergreen trees such as néré, karité, A. nilotica and mango. Under large néré trees, as little as $20 \%$ of photosynthetically active radiation (PAR) reached the ground near the bases of trees and $91 \%$ at $14 \mathrm{~m}$ away from the bases; PAR transmission generally increased from $43 \%$ near the bases of trees to $90 \%$ beyond their crowns (Kessler, 1992). Jonsson et al. (1997) recorded on average only $25 \%$ of the PAR of the open area under the canopies of both néré and karité, which could cause about 50\% yield reduction in pearlmillet (Pennisetum glaucum). While competition for light is the major limiting factor for crop 
growth under tree canopies, competition for water and nutrients could be the major factors beyond the crown areas.

Aboveground competition (i.e., for light) and belowground competition (i.e., for water and nutrients) may both be important under boundary plantings, as was demonstrated in a study in Uganda that used a root mesh to prevent lateral root spread (Okorio et al., 1994). When trees of four species were 3.5 years old, crop yields adjacent to trees without root mesh were $20 \%$ to $55 \%$ of yields in the treeless open area. When root mesh was installed to $0.5-\mathrm{m}$ depth and $0.5 \mathrm{~m}$ away from trees, yields increased by $152 \%$ adjacent to Maesopsis eminii, 57\% adjacent to Markhamia lutea and $16 \%$ adjacent to Casuarina cunninghamiana. However, the presence of root mesh did not restore crop yields to open-area levels, suggesting the existence of aboveground competition. No study, to our knowledge, has separated the trees' competition for nutrients from that for water, although competition for water is considered to be far more important than that for nutrients in semiarid and subhumid climates. Aboveground competition can be reduced by side-pruning of trees and belowground competition by periodic root pruning (e.g., by deep plowing), although the feasibility for managing root competition is questionable on many tropical farms.

\section{Microclimate}

Trees in croplands bring about microclimate changes under their canopies by reducing soil and air temperature, irradiance and wind speed. These changes will have direct influence on soil water evaporation and humidity, which in turn may significantly affect crop growth, depending on the climate. In the SAT savanna of Kenya, baobab and Acacia tortilis trees reduced soil temperature under their crowns by $6^{\circ} \mathrm{C}$ at $5 \mathrm{~cm}$ and $10 \mathrm{~cm}$ depth, compared with open areas (Belsky et al., 1993). In the Sahel, faidherbia trees lowered soil temperature at $2-\mathrm{cm}$ depth by $5^{\circ}$ to $10{ }^{\circ} \mathrm{C}$ depending on the movement of shade (Vandenbeldt and Williams, 1992). Soil temperatures in the Sahel often reach lethal levels of $50^{\circ}$ to $60^{\circ} \mathrm{C}$ at the beginning of the rainy season, causing poor establishment of millet (Soman et al., 1987). A reduction of $10{ }^{\circ} \mathrm{C}$ in soil temperature greatly reduces the detrimental effect of high temperature and improves crop stand establishment. Recent studies in Burkina Faso showed that topsoil temperature under néré and karité trees was lower than in the open areas throughout the cropping season (Figure 4). Shade of 30- to 100 -year-old trees, with $60-$ to $130-\mathrm{m}^{2}$ crown areas, resulted in lower soil temperatures than shade of smaller trees (Jonsson et al., 1997). Wind speed was also reduced under the canopies, particularly in the later part of the season, which is dominated by the desiccating harmattan winds (Jonsson et al., 1997). The reduced radiation load and windspeed under canopies reduce water demand by crops and soil evaporation, which are particularly important during drought periods.

Trees contribute to loss of rainfall through evaporation of canopy interception, and modify soil water conditions under canopies by shading and redis- 


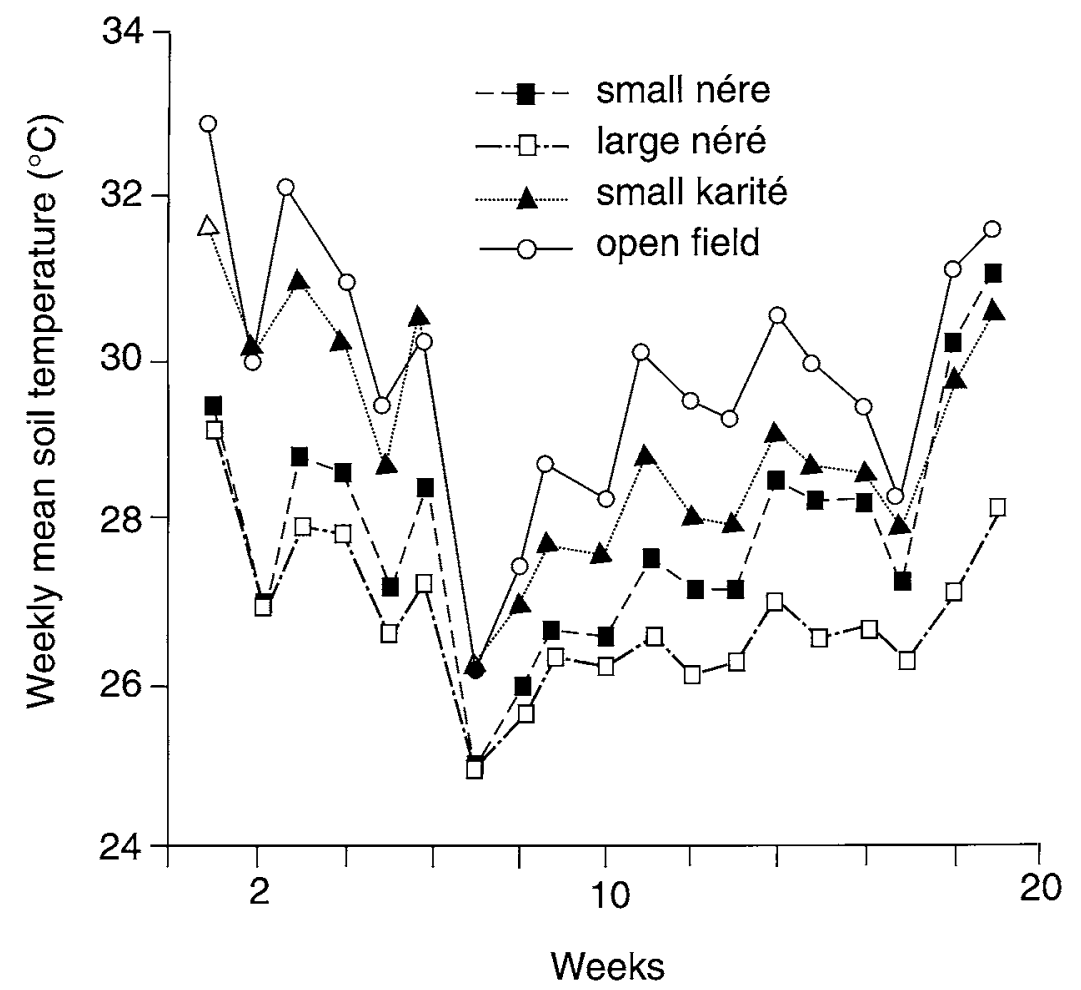

Fig. 4. Weekly mean soil temperature at 5-cm depth, measured at Saponé, Burkina Faso, from 29 June to 15 November 1994 under large and small trees of néré (Parkia biglobosa) and small trees of karité (Vitellaria paradoxa), and in the open field. Tree crown diameters ranged from an average of $8.6 \mathrm{~m}$ to $13.1 \mathrm{~m}$. (Source: ICRAF, 1996).

tribution of intercepted rain through stem flow and canopy drip (Wallace, 1996). Fully foliated trees may cause up to a $50 \%$ loss of rain water for small storms (< $15 \mathrm{~mm}$ precipitation) but a 10 to $20 \%$ loss for larger storms $(>15$ $\mathrm{mm}$ precipitation). Individual trees on an annual basis may account for $10 \%$ to $15 \%$ loss of rainfall in the tropics (Breman and Kessler, 1995). However, on the positive side, tree canopies will reduce evaporation of water from soil, which is particularly important in areas where rainfall frequently occurs in light showers, such as in the highlands. Wallace et al. (1997) predicted that the reduction in soil evaporation under tree canopies would be sufficient to offset the increased losses due to canopy interception at a semiarid site in Machakos, Kenya. Their model was used to demonstrate how annual total soil evaporation varied with soil type and rainfall climate. The largest amounts of soil evaporation and the greatest saving in soil evaporation due to canopy shade were found in clay and sandy loam soils, and the least were found in sandy soils. Rainfall intensity and annual total were shown to be important determinants of soil evaporation under tree canopies. 
Crop yields

Crop yields under trees may be unaffected during the early years of tree growth, but could increase or decrease when trees are large, depending on the tree species. Any positive influence of trees on crop yields through soil fertility improvement would not be expected for many years, as trees modify the soil environment slowly. It has been postulated that the beneficial effects of faidherbia on crop yields will start only after the trees are from 20 to 40 years old (Poschen, 1986). On the other hand, the negative effect of trees because of competition for growth resources can be noted within a few years. The slow-growing trees such as faidherbia and acacia may not influence crop yields for many years after their establishment (Okorio and Maghembe, 1994), but the fast-growing trees such as poplars and eucalyptus reduce crop yields fairly quickly, within two to three years after their establishment (Ralhan et al., 1992; Akyeampong et al., 1995b).

Crop yield increases have been widespread under open and well-managed canopies of fully grown trees. Reported yield increases under faidherbia are: maize by more than $100 \%$ in Malawi (Saka et al., 1994), and $76 \%$ in Ethiopia (Poschen, 1986); sorghum (Sorghum bicolor) by 36\% in Ethiopia (Poschen, 1986) and $125 \%$ in Burkina Faso (Depommier et al., 1992); and millet by $250 \%$ in Senegal (Charreau and Vidal, 1965). These yield increases under faidherbia (often referred to as the 'albida effect') are attributed to the combined effects of improved soil fertility, soil water and microclimate. The relative importance of these causal factors depends on soil and climatic conditions. Increased nutrient availability through mineralization of SOM is responsible for higher yields in nutrient-depleted soils (Rhoades, 1995). In the Sahel, about $60 \%$ of the 'albida effect' was estimated to be due to increased nitrogen availability and $40 \%$ due to increased phosphorus availability (ICRAF, 1997). Other contributory factors could be more important in drier climates. For example, reduction of soil temperature by partial shading of the soil surface is important in the Sahel to improve crop stand, particularly when early season rainfall is erratic, and to reduce the detrimental effect of high temperature on crop growth later in the season (Vandenbeldt and Williams, 1992; Jonsson et al., 1997).

Crop yield declines, relative to yields in open, treeless fields, are noted mostly under the canopies of large, evergreen, unmanaged trees. In Burkina Faso, sorghum yields under karité and néré trees were reduced on average by $50 \%$ and $70 \%$ respectively (Kessler, 1992). Sorghum yields were reduced by up to $60 \%$ under canopies of both these species in southern Mali (Kater et al., 1992). In India, wheat yields were reduced by up to $60 \%$ (Puri and Bangarwa, 1992) and mustard (Brassica sp.) yields by up to 65\% (Yadav et al., 1993) under A. nilotica trees. In environments where seasonal rainfall (above approximately $800 \mathrm{~mm}$ during the cropping season) or irrigation provide adequate water for crop growth, reduction of crop yields under trees is mainly due to reduced light. A significant negative correlation between yield and light under néré and karité canopies indicated that shade was the major factor for the 50\% 
to $70 \%$ reduction of sorghum yields under those trees (Figure 5). Increased humidity under trees might favor the development of fungal diseases which may affect crop stand and contribute to yield reduction (Kater et al., 1992). Pruning reduces light competition to some extent, and may provide tree products such as fuelwood and fodder, and additional benefits through enhanced fruit production in certain tree species (Timmer et al., 1996).

The effect of boundary plantings of trees on crop yields depends on the site and age of the trees. At Hissar, India, 3.5-year-old Eucalyptus tereticornis on field boundaries reduced crop yields by $41 \%$ up to $10 \mathrm{~m}$ from the tree row (Malik and Sharma, 1990). Similarly, crop yield losses were observed at Machakos, Kenya, beginning two years after tree establishment, but different tree species showed distinctly different patterns of competition depending on growth rates and rooting pattern (Figure 6). The fast-growing grevillea and the slow-growing croton (Croton megalocarpus) depressed crop yields only over a short distance from the trees $(<3 \mathrm{~m})$. At $3 \mathrm{~m}$ from the tree row, crop yields in the grevillea and croton plots approached that of the control plot, but gliricidia adversely affected yields for up to $4 \mathrm{~m}$ from the tree row. Although Senna spectabilis had faster height growth than the other tree species, it depressed yields least, probably because of its limited canopy and deeper rooting. Melia volkensii, which produced the most growth, was also the most competitive species; it depressed crop yields for up to $5 \mathrm{~m}$ from the tree row because of its large canopy and probably its lateral spread of roots near the soil surface. At $6 \mathrm{~m}$ from the tree row, there was little impact of any of the tree species on crop yields. It is interesting to note that contrary to the

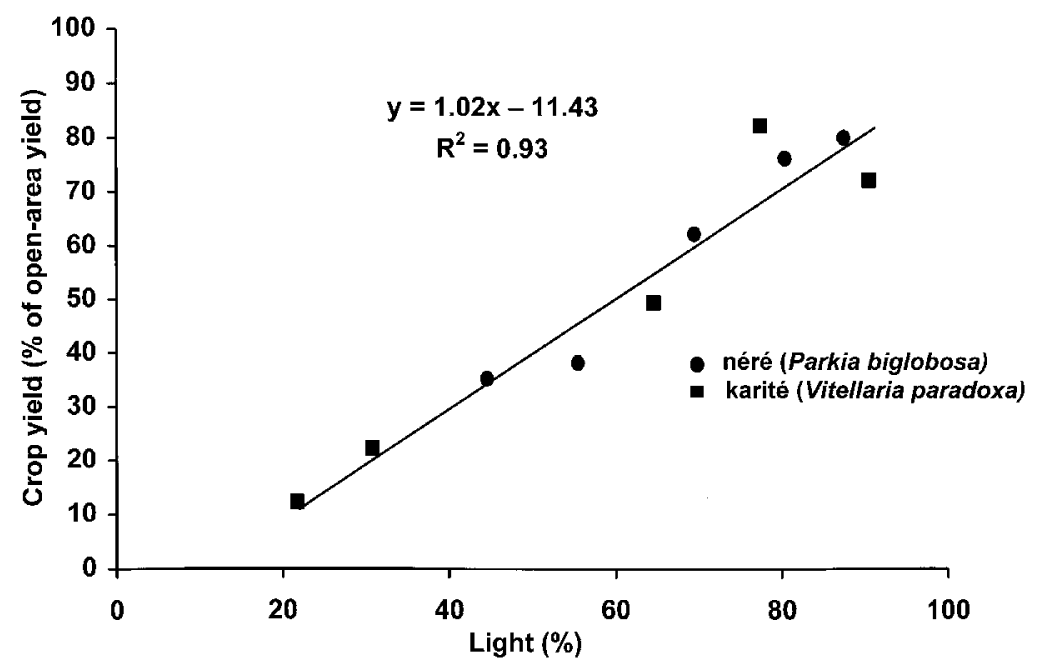

Fig. 5. Relationship between photosynthetically active radiation (PAR) transmitted and sorghum (Sorghum bicolor) yield under néré (Parkia biglobosa) and karité (Vitellaria paradoxa) canopies, measured at different distances from the base of trees, in Burkina Faso. (Source: adapted from Kessler, 1992). 


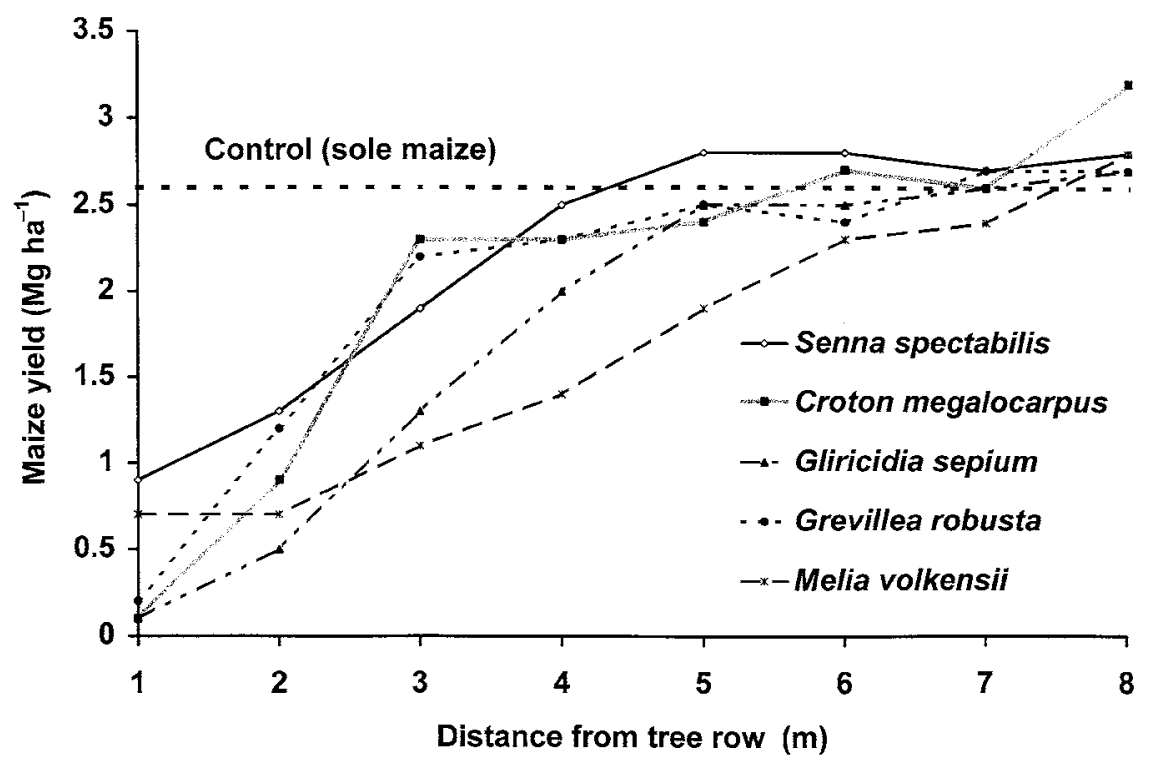

Fig. 6. Maize yield measured at different distances from tree rows of five different tree species in the 1995 first rainy season, two years after the establishment of trees, at Machakos, Kenya. (Source: ICRAF, 1996)

general view, the indigenous tree melia $(M$. volkensii) was the most competitive and the exotic species, grevillea and senna, the least competitive. Large differences among species for competitiveness were also observed three years after trees were established on field borders in Uganda (Okorio et al., 1994). Over 3 to $4 \mathrm{~m}$ from the tree row, crop yield effects ranged from a $60 \%$ yield loss adjacent to the fast-growing Maesopsis eminii to a $19 \%$ yield increase adjacent to the slow-growing and nitrogen-fixing Alnus acuminata. These studies point out the need for careful selection of tree species based on their growth rates, canopy and rooting characteristics. Trees become more competitive with age (and increased size), as illustrated by a progressive reduction of maize yields over $7.5 \mathrm{~m}$ on each side of a row of unpruned leucaena trees at Machakos, Kenya (Figure 7). After a certain number of years, however, the competitive effect of trees might be independent of tree age because all trees will have attained a large size (Khybri et al., 1992).

It must be recognized that in spite of large yield increases or decreases under scattered trees and near boundary plantings, the overall effect of trees on crop yields could be small because only a small proportion of the area is subjected to tree/crop interactions. Consider a scattered-tree system that contains 20 trees ha ${ }^{-1}$ with each tree affecting crops over a $100 \mathrm{~m}^{2}$ area. If the trees increase or decrease crop yields by $50 \%$ over that area, the overall yield of the system will be only $10 \%$ higher or lower than that of sole crop. Similarly, if a boundary planting of a $100-\mathrm{m}$ tree row reduces crop yield by 


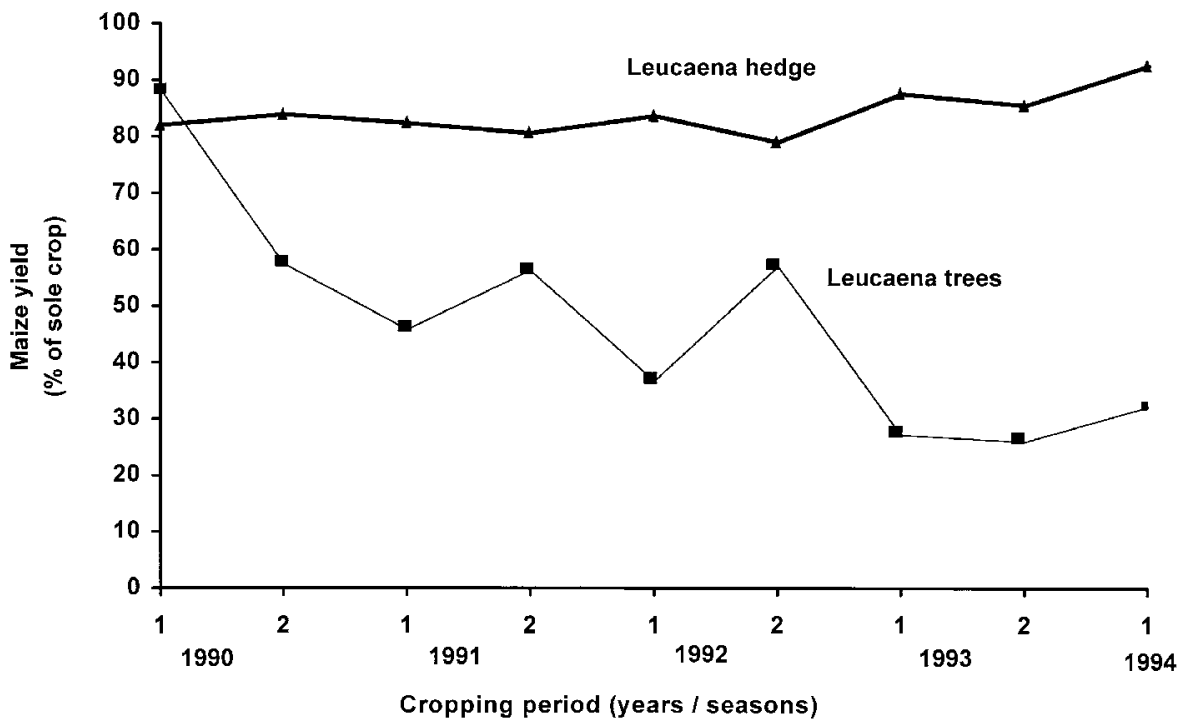

Fig. 7. Maize yield as affected by competition of unpruned Leucaena leucocephala trees and periodically pruned hedgerows during five years, since the establishment of Leucaena in November 1989 at Machakos, Kenya. Crop yields in the first and second rainy seasons in each year are indicated by 1 and 2 respectively. (Source: Rao MR and Mathuva MN, unpublished)

$50 \%$ over a $10-\mathrm{m}$ distance on either side, then the yield of the system as a whole over one hectare is reduced by only $10 \%$ (or $5 \%$ to each neighboring farmer).

\section{Conclusions}

Trees improve soil fertility and modify the microclimate both favorably and unfavorably under their canopies depending on tree species; the magnitude of change depends on canopy and root characteristics, age and size of trees, and density. Boundary plantings generally reduce crop yields but the effect extends over a relatively small area. The overall productivity of simultaneous systems depends on: (1) the complementarity of resource use by the components, especially by trees drawing resources from zones unexploited by crops, (2) the efficiency of nutrient cycling, and (3) the net value of harvested tree products relative to the net value of crop products that could be produced with the resources used by trees. Furthermore, the prospects for regular availability of tree products could reduce farmers' risk in the event of crop failures, for example, during drought which affects crops more seriously than trees.

Competition of trees can be managed to some extent by pruning, maintaining the appropriate density and sequential thinning; however, the scope for management of belowground competition is limited to the choice of trees which have deep and compact root systems. Whether tree density can be increased in parklands where crop yields are higher under trees than in the 
open (e.g., under faidherbia trees) depends on the nature of the processes that contribute to increased yields. The scope for higher stand density exists if increased yield is related to improved microclimate or increased fertility due to BNF and uptake of nutrients unexploited by crops, but not if it is due to concentration of nutrients by lateral exploitation. There is little scope for increasing faidherbia density in parklands beyond about 30 trees ha ${ }^{-1}$ at the mature stage because yield increases under faidherbia are due mostly to improved soil fertility, which is caused not solely by BNF.

\section{Allelopathy}

Allelopathy is discussed here as applicable to all agroforestry systems. If allelopathy exists, its effects could be more important in simultaneous systems than in sequential systems because of the permanent presence of trees and direct exposure of crops to the continuous release of chemicals. Although allelochemicals may be present in practically all tree parts (leaves, flowers, seeds, fruits, stems, roots, rhizomes), information on the nature of active chemicals and their mode of action is lacking (Rice, 1984). The effects of these chemicals on other plants are known to be dependent on the concentration as well as the combination in which one or more of these substances are released into the environment (Putnam and Tang, 1986). Considerable progress has been made in understanding the nature of allelochemicals and the extent of negative effects and potential benefits in annual cropping systems.

Several studies have reported the deleterious allelopathic effects of certain agroforestry trees on crops (Bhatt and Todaria, 1990; Willis, 1991; Nandal et al., 1994). Most allelopathy literature is based on laboratory studies or bioassays conducted under controlled conditions, using unrealistic concentrations of aqueous leachates or extracts of tree parts (Bhatt and Todaria, 1990; Nandal et al., 1994; Rice, 1984), and it is not clear to what extent these results have practical value. Even though certain trees may release harmful chemicals into soil through leaf litter or root secretion, they may have only temporary or no effect on crops under field conditions because of rapid elimination of chemicals by soil microorganisms and/or leaching, particularly in the humid environments. The practical significance of allelopathy cannot be ascertained unless the effect of allelochemicals on crop yields is demonstrated under field conditions, independent of the competition of trees for water and nutrients (Willis, 1991), and independent of the temporary immobilization of plant nutrients due to the addition of low quality tree litter (Sanginga and Swift, 1992).

The few field studies that reported allelopathic effects under field conditions were mostly concerned with poor germination and early growth of seedlings either under trees or after the application of tree prunings. Plant stand of many field crops (maize, pigeonpea (Cajanus cajan), beans, and groundnut (Arachis hypogaea)) was poor in the vicinity of Gmelina arborea 
in Malawi because of suspected allelopathy (J. Maghembe, pers. comm.). Boundary plantings of eucalyptus have been widely reported to affect adjacent crops due to allelopathy (Willis, 1991). Lal (1989a) reported poor germination and seedling establishment of cowpea in leucaena and gliricidia hedgerow systems in Ibadan, Nigeria, which often resulted in lower yields of cowpea under HI than in sole crop control. Interestingly, maize germination was not affected by the hedgerows. Similar observations have been made on cowpea at ICRAF's Machakos research station in Kenya (authors' unpublished data). Tian and Kang (1994) reported that gliricidia prunings at $5 \mathrm{Mg} \mathrm{ha}^{-1}$ caused $90 \%$ leaf chlorosis on maize and cowpea but the deleterious effect disappeared very soon or could be avoided by incorporating the material into the soil one week before crop sowing. However, the extent of allelopathic interaction cannot be determined from such studies because the observed results could have been caused by nutrient-related (especially N) soil factors. Early growth of maize seedlings was poor on plots mulched with grevillea at $4.6 \mathrm{Mg} \mathrm{ha}^{-1}$ in Machakos, Kenya, probably due to the same manganese toxicity that was observed in pot studies (Yobterik et al., 1994). Compared with the positive soil fertility effect of prunings or the negative competitive effect of trees for growth resources, the effect of allelopathy is probably of much less importance. Allelopathy could be beneficial through reduced weed emergence but the scope for selective reduction of weeds without affecting crops has not been investigated in agroforestry systems.

\section{Sequential systems}

\section{Improved fallows}

In improved fallows, selected tree (or herbaceous) species are either planted or retained from natural regeneration with some management. We restrict our discussion in this paper to planted tree fallows. Two categories of planted tree fallows can be distinguished: (1) short-duration fallows with fast-growing, leguminous trees or shrubs established primarily to replenish soil fertility to support food crop production, and (2) medium- to long-duration fallows with diverse species established for amelioration of degraded and abandoned lands as well as for utilization of tree products. Planted fallows are an improvement over natural fallows in that the objectives for which natural fallows have traditionally been used are attained in a shorter time through manipulation of management operations such as choice of tree species, spacing, density, establishment, and pruning.

In the rotation system of tree fallows followed by crops, three distinct phases can be distinguished based on the major soil changes that occur (Figure 8): (1) restoration (or fallow) phase, when the tree fallow accumulates nutrient stocks in the standing biomass through gains from natural processes (e.g., BNF) and recovery of lost nutrients (e.g., uptake from deeper 
soil layers), reduces weeds and pathogens, and improves other soil parameters, (2) nutrient transfer (or fallow clearing) phase when nutrient stocks in the vegetation are added to soil through fallow clearing, and (3) degradation (or cropping) phase, when nutrients are depleted through crop harvests, weeds and pests may increase, and soil conditions deteriorate. Tree fallows can be cleared for the subsequent cropping phase by either the slash-and-burn or slash-and-mulch technique, but these procedures have distinctly different effects on soil chemical, physical and biological processes (Figure 8). Nutrient cycling in the traditional slash-and-burn systems has been the subject of discussion of many papers (e.g., Sanchez and Hailu, 1996). We discuss in the following sections the tree-soil interactions in planted fallow systems and their effect on later crop yields.

\section{Soil fertility: chemical}

The major soil chemical changes that take place under tree fallows are increases of labile pools of SOM, N stocks, exchangeable cations and extractable P. Details of the mechanisms of soil improvement by tree fallows (as outlined in Table 1) are reviewed by Buresh and Tian (1997) and Szott et al. (1998). Planted fallows are expected to improve soil faster than HI and natural fallows because the land is completely occupied by fast-growing tree species that are specifically chosen for this purpose. However, the magnitude of improvement depends on tree species, length of fallow, soil and climatic conditions.

Significant increases in soil organic $\mathrm{C}$, total $\mathrm{N}$ and exchangeable cations were observed in the topsoil even after short-duration fallows. For example, these variables were increased relative to initial soil conditions on nutrientdepleted soils in western Kenya, following one-year fallows of pigeonpea (Cajanus cajan) and leucaena (Onim et al., 1990), and in a one-year tephrosia (Tephrosia vogelii) fallow compared with grass fallow in Cameroon (Prinz, 1986). In Nigeria, two-year-old Tephrosia candida and pigeonpea fallows increased soil organic $C$ and total $N$ over natural bush in the surface $0-5 \mathrm{~cm}$ soil layer (Gichuru, 1991). In Zambia, a two-year sesbania fallow added 94 to $135 \mathrm{~kg} \mathrm{~N}$ and 10 to $15 \mathrm{~kg} \mathrm{P} \mathrm{ha}^{-1}$ through 3.4 to $4.5 \mathrm{Mg} \mathrm{ha}^{-1}$ of leaves, twigs and litterfall and 1.7 to $2.9 \mathrm{Mg} \mathrm{ha}^{-1}$ of belowground biomass; while $\mathrm{N}$ addition was through BNF and recycling from depth, all of the $\mathrm{P}$ was through recycling (Torquebiau and Kwesiga, 1996). An 18-month-old sesbania fallow in the highlands of western Kenya has recycled $135 \mathrm{~kg} \mathrm{~N}$ and $4.5 \mathrm{~kg} \mathrm{P} \mathrm{ha}^{-1}$ through $2 \mathrm{Mg} \mathrm{ha}^{-1}$ of leaves and pods and $3.3 \mathrm{Mg} \mathrm{ha}^{-1}$ of litterfall (ICRAF, 1997). In the subsequent cropping phase, the plots planted with sesbania fallow recorded significantly higher mineral $\mathrm{N}$, higher rates of $\mathrm{N}$ mineralization and higher $\mathrm{N}$ associated with light fraction SOM than plots with grass fallow; these three indices of $\mathrm{N}$ availability were highly correlated with subsequent maize yields (ICRAF, 1996).

In the lowlands of Costa Rica, significant soil improvements were observed under short- and long-term woodlot plantations, irrespective of whether the 


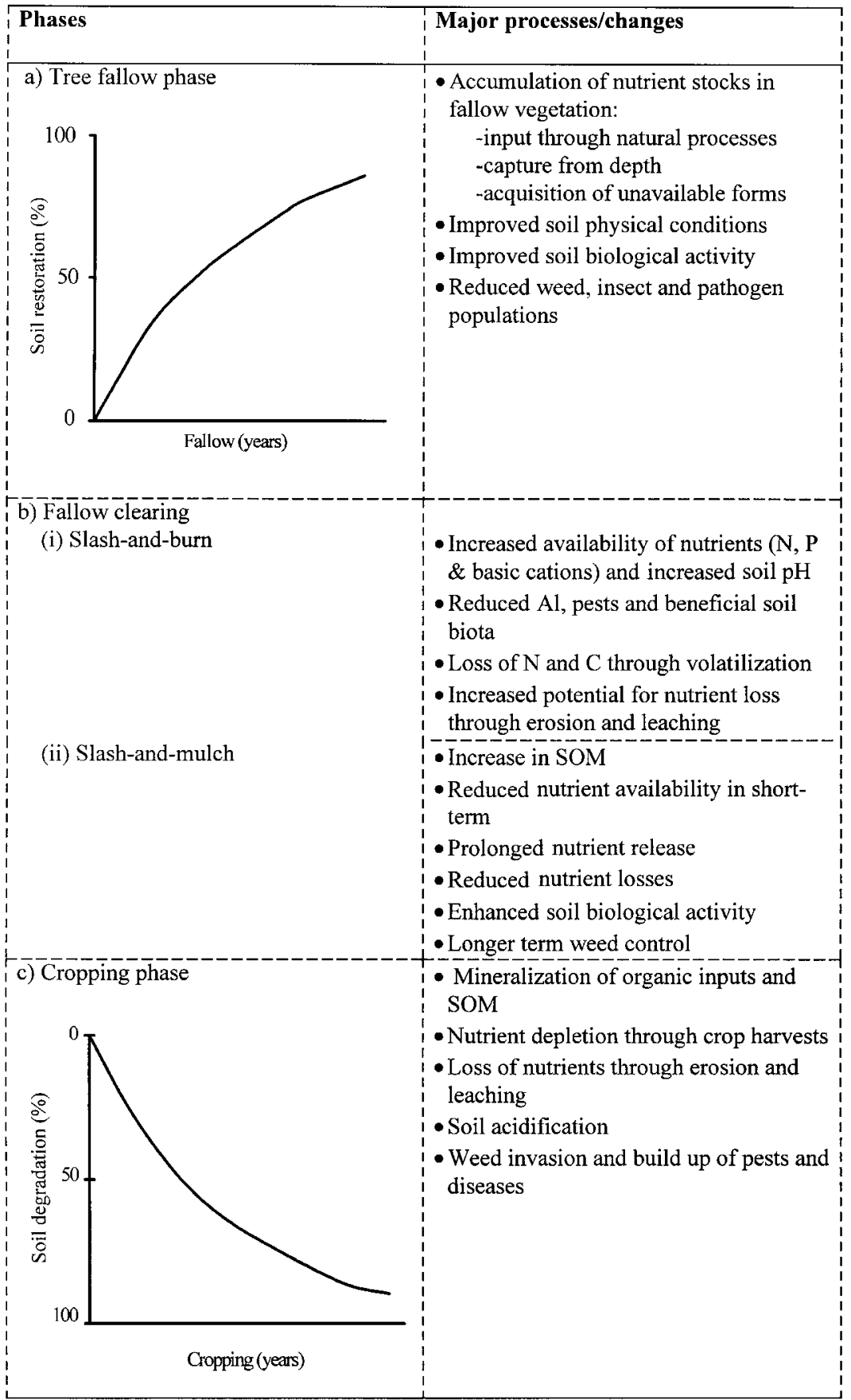

Fig. 8. Summary of soil processes/changes as a result of tree-soil-crop interactions during different phases of tree fallow-crop rotation cycles. 
trees were $\mathrm{N}_{2}$ fixing (Montagnini and Sancho, 1990); total N, Ca and P were increased, relative to a grass fallow, under 30-month-old stands of a number of valuable indigenous trees. However, soil nitrate- $\mathrm{N}$ content was higher only under leguminous trees. On acrisols in Togo, Drechsel et al. (1991) recorded $40 \%$ to $60 \%$ improvement of SOM, CEC and exchangeable cations in the $0-15$ $\mathrm{cm}$ soil layer under five-year-old trees of Acacia auriculiformis, S. siamea and Albizia sp., and $115 \%$ increase of SOM under neem, compared with grass fallows. On N-deficient soils in Tanzania, Jonsson et al. (1996) also noted significant species differences in effects on soil characteristics; $\mathrm{N}_{2}$-fixing leucaena and Prosopis chilensis showed greater positive changes than non$\mathrm{N}_{2}$-fixing eucalyptus or $S$. siamea.

There are also several reports on tree stands causing changes in soilreaction. Topsoil $\mathrm{pH}$ decreased under the fallows of Acacia auriculiformis (Drechsel et al., 1991) and eucalyptus (Jonsson et al., 1996), it remained unaffected under leucaena and P. chilensis (Jonsson et al., 1996) and it increased under neem, S. siamea and albizia (Drechsel et al., 1991) and leucaena, Sesbania sesban and pigeonpea (Onim et al., 1990). The $\mathrm{pH}$ changes are mostly the result of relocation of basic cations within the soil profile. The small changes that may take place after fallows will have little effect on crop yields in base-rich soils. However, the significant changes that occur on acidic, low-activity-clay soils in the humid tropics during tree fallow and the subsequent clearing process will have a major effect on crop growth. The decreases of $\mathrm{pH}$ during the fallow phase, which may be accentuated by fallow length (Adejuwan and Adesina, 1990), were probably related to leaching of basic cations as a result of leaching of excess nitrates and hydrogen released during BNF, and to uptake of cations from depth and their storage in the standing biomass. However, soil $\mathrm{pH}$ increases following the slash-and-burn of fallow vegetation. Any increase in $\mathrm{pH}$ under tree fallows was probably due to transfer of cations from depth to the soil surface via deep root uptake and litterfall.

Planted tree fallows have also been useful in ameliorating saline and alkali soils by leaching of salts beyond the crop root zone. On such soils in India, 30-month-old $S$. sesban decreased soil $\mathrm{pH}$, and increased soil organic C (40\%), total $\mathrm{N}(15 \%)$, and available $\mathrm{N}(53 \%)$ in the $0-30 \mathrm{~cm}$ soil layer (Rao et al., 1990). Production of a large quantity of biomass (30 to $40 \mathrm{Mg} \mathrm{ha}^{-1}$ ) with high potential for BNF (312 to $466 \mathrm{~kg} \mathrm{ha}^{-1} \mathrm{yr}^{-1}$ ) and its in situ decomposition were the major avenues for substantially reducing soil $\mathrm{pH}$ and ameliorating the saline and alkali soils. Long-term tree stands of a number of species (Prosopis juliflora, Eucalyptus tereticornis, Terminalia arjuna, Albizia lebbeck and Acacia nilotica) were also found to improve the soil chemical characteristics of salt-affected soils in India (Singh et al., 1994). Obviously, the extent of soil improvement depends on the length of fallow, with greater improvements following longer fallows (Adejuwan and Adesina, 1990; Mulongoy et al., 1993).

Compared with other nutrients, soil P did not change consistently under 
tree fallows. Onim et al. (1990) noted 85\% lower extractable P compared to the initial level, one year after shrub fallows, on a P-deficient site in Kenya. Drechsel et al.(1991) observed higher soil P under cassia and neem than under albizia and A. auriculiformis. Adejuwan and Adesina (1990) did not find any relationship between length of gliricidia fallows and available $\mathrm{P}$ in the soil. Jonsson et al. (1996) reported a decrease of extractable soil P under eightyear-old tree stands. The decrease in extractable soil $\mathrm{P}$ resulted from uptake by trees and its storage in the standing tree biomass. Although trees have little scope to increase the supply of total soil P, they can acquire some unavailable forms of inorganic soil $\mathrm{P}$ by mechanisms such as mycorrhizal association (Bolan, 1991; Mason and Wilson, 1994) and secretion of weak acids (e.g., by pigeonpea, Ae et al., 1990), and thereby increase the plant-available forms of organic P following the return of tree residues to the soil (Tiessen et al., 1992; Buresh and Tian, 1997). The inability of fallow systems to meet the $P$ requirements of crops highlights the need for $\mathrm{P}$ fertilizer use, especially on P-deficient soils, to ensure efficient fallow function and realize high productivity of crops (Palm, 1995). Fallow clearing by slash-and-burn does not lose phosphorus accumulated in the fallow vegetation.

\section{Soil fertility: physical}

Tree fallows improve soil physical properties due to the addition of large quantities of litterfall and root biomass (Schroth et al., 1995a), root activity of trees, biological activity and tree roots leaving macropores following their decomposition (van Noordwijk et al., 1991). Planted fallows of leucaena and sesbania improved soil physical conditions, compared with natural fallows or continuous cropping, as was evident from lower bulk density and reduced resistance to penetration in the surface soils at the end of the fallow phase. The consequence of these changes was greater infiltration and higher water storage under fallows (Juo et al., 1996; Torquebiau and Kwesiga, 1996). Tree roots can reach deep depths, penetrate compacted soil layers and improve subsoil structure and, thus, increase water infiltration and water storage. Roots of two-year-old sesbania were found to penetrate up to 5-m depth, and root mass in the $2 \mathrm{~m}$ soil profile accounted for $37 \%$ of the total biomass added (litterfall, foliage and roots) to the system (Torquebiau and Kwesiga, 1996). Species may differ greatly in their ability to root deeper and penetrate hard layers. Tree species with high root mass should be preferred for rehabilitation of physically degraded soils (Schroth et al., 1996).

\section{Soil fertility: macrofauna}

Accumulation of litter on the soil surface and microclimatic changes might lead to increased activity of soil macrofauna under tree fallows, particularly in the subhumid and humid environments. However, only a few studies have measured soil faunal activity under planted fallows, compared with natural fallows or continuous cropping. Observations made at Muguga, Kenya under natural forest, continuously cropped maize, one-year-old sesbania fallow, and 
grass fallow indicated that sesbania fallows restored the soil biological activity to the same level as in natural forest (Table 4). Although the diversity of faunal groups was not high, the total biomass of all groups under sesbania was several-fold higher than in the cropped fields or grass fallows. Of particular interest was the large increase under sesbania fallows of faunal groups such as earthworms and termites. Tian et al. (1993) working under subhumid conditions in Nigeria reported similar results and suggested that the increased faunal activity was due to the high quality of sesbania litter. Cases of increased soil faunal activity under planted fallows are also reviewed by Buresh and Tian (1997). The increased soil fauna will play a significant positive role in litter decomposition, mineralization of nutrients and improvement of soil structure by incorporating SOM into stable soil aggregates.

\section{Weed control}

Shade-based control of weeds is an essential aspect of the traditional bush fallow and planted-tree fallow systems. Two distinct phases can be recognized: initial suppression of aboveground weed growth, and subsequent depletion of the weed seed-bank. Natural fallows may control aboveground weeds within six years (Ramakrishnan and Misra, 1981), but a continuous canopy of 10 years or more is required to reduce the viable weed seed-bank (De Rouw, 1995; Staver, 1991). If selective weeding is done to retain certain species of natural vegetation, the weed suppression phase may be reduced to, for example, 0.5 to 1 year, as in the Täi farm system, Cote d'Ivoire (De Rouw, 1995). Such a practice will help increase land-use intensity.

Planted fallows can smother both annual and perennial weeds by the combined effect of reduced light and a thick mulch layer formed by canopy

Table 4. Biomass of macrofaunal groups under different land-use systems at Muguga, Kenya.

\begin{tabular}{lrccl}
\hline Group & Natural forest & $\begin{array}{c}\text { Sesbania fallow } \\
\text { Macrofauna biomass }\left(\mathrm{g} \mathrm{m}^{-2} \text { of } 0-30 \mathrm{~cm} \text { soil depth }\right)-\end{array}$ & $\begin{array}{c}\text { Grass fallow } \\
\text { Marthworms }\end{array}$ & \multicolumn{2}{c}{ Maize monocrop } \\
\hline Woodlice & 0.34 & 9.58 & 3.34 & 0.92 \\
Millipedes & 15.42 & 0 & 0.01 & 0 \\
Centipedes & 0.05 & 0.03 & 2.19 & 0.53 \\
Termites & 0.06 & 3.77 & 0.22 & 0 \\
Cockroaches & 0.11 & 0 & 2.41 & 0.14 \\
Crickets & 0.08 & 0 & 0.05 & 0 \\
Beetle larvae & 0.66 & 3.91 & 0 & 0 \\
Beetle adults & 0.78 & 0.17 & 3.04 & 2.44 \\
Ants & 0.11 & 0.05 & 0.53 & 0.12 \\
Spiders & 0.02 & 0.10 & 0.25 & 0.05 \\
Others & 0.05 & 2.20 & 0.02 & 0 \\
Total & 21.25 & 19.81 & 0.02 & 0.01 \\
\hline
\end{tabular}

Source: J. M. Dangerfield, 1993 (unpublished). 
leaf litter. The potential of fallow, however, depends on the weed species, fallow species, tree density, length of fallow and management in the initial establishment phase. Although tree fallows may take more time than shrubs and prostrate plants to suppress aboveground weeds, they could be equally effective on a longer term in controlling perennial weeds and reducing the weed seed-bank. In the humid tropics of Peru, the herbaceous fallow of Centrosema macrocarpum reduced weed populations to a very low level within a few months of its establishment. Although the slow-growing pigeonpea and inga tree fallows recorded higher weed growth than natural fallows or C. macrocarpum during the first 18 months after establishment, the weed population was similar to that under natural fallows by 29 months (Figure 9). After 32 months, weed growth was similar in all systems, and continued to be similar during the remaining fallow period ( 21 months) and the subsequent first crop. Weed growth in all systems started to increase during the cropping phase, but more rapidly in pigeonpea than in the others. In southern Africa, two-year fallows of sesbania and Acacia angustissima were found to reduce annual weeds effectively (K. Kwesiga and B. Dzowela, pers. comm., 1996). Peltophorum and chromolaena (Chromolaena odorata) fallows were found to smother annual weeds similarly in north Lampung, Indonesia (M. van Noordwijk, pers. comm., 1996).

It is also feasible that perennial grass weeds such as imperata (Imperata cylindrica) can be controlled through planted tree fallows, once the trees are well established (Garrity, 1997). On Alfisols in Nigeria, ten months of fallow growth of well-established leucaena and gliricidia hedgerows reduced the population of imperata by $51 \%$ to $67 \%$, aboveground biomass by $78 \%$ to

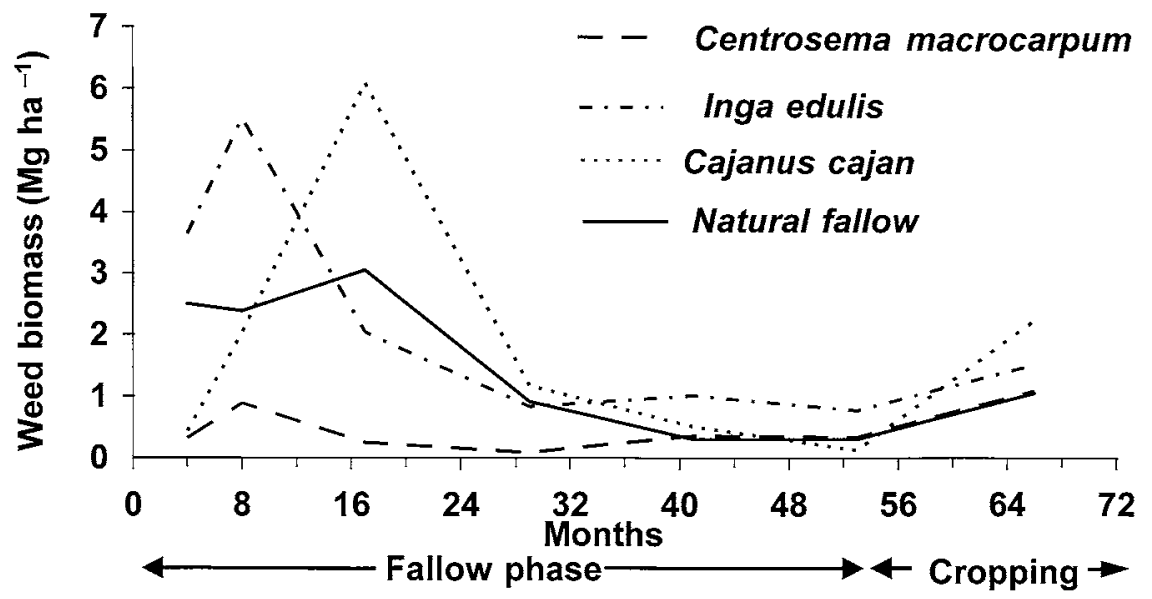

Fig. 9. Weed biomass in herbaceous legume (Centrosema macrocarpum), woody shrub (Cajanus cajan) and tree (Inga edulis) fallows compared with natural fallow during a 53-month fallow phase and a 12-month subsequent cropping phase at Yurimaguas, Peru (Source: Szott LT, Palm $\mathrm{CA}$ and Davey CB, unpublished). 
$81 \%$ and belowground rhizomes by $90 \%$ to $96 \%$ (Anoka et al., 1991). On Ultisols in north Lampung, Indonesia, the shade of unpruned hedgerows in a rotational fallow-HI system suppressed imperata population to a 'manageable' level; the hedgerows of gliricidia, peltophorum, or a combination of the two species were the most effective in controlling the grass (ICRAF, 1996). Fallow stands of Acacia mangium eliminated imperata in four to five years in Sabah, Malaysia (Miller and Hepburn, 1991). There seems to be a good prospect of controlling imperata in even a shorter period with closely planted peltophorum fallows (M. van Noordwijk, pers. comm., 1996) or by properly managing chromolaena (Akobundu and Ekeleme, 1996). For successful shadebased control of imperata, the tree species employed should be fire-tolerant and capable of regenerating quickly, as imperata lands are prone to fire hazards. The planted fallow technologies might be the most economical and effective strategy for small farmers to bring into cultivation the abandoned grasslands in the humid tropics.

On-going research at ICRAF on short-duration planted fallows has indicated the potential of certain fallow species to reduce infestations of the parasitic weed, striga. Sesbania fallows of 1.5 to 2 years duration have reduced infestations of Striga asiatica in Zambia (ICRAF, 1995) and S. hermonthica in western Kenya (H. Sjögren, pers. comm., 1996) on the subsequent maize crop. The decrease of striga could be partly due to increased soil fertility, which has a negative effect on striga incidence, and to sesbania acting as a false host (Oswald et al., 1996).

Effect of planted tree fallows on crop yields

Sequential systems using planted tree fallows have not received the same attention as HI, but the few studies undertaken so far illustrate the positive effect of tree fallows on crops. Short-duration fallows with herbaceous legumes have been examined widely and found to increase yields of subsequent crops compared with grass fallows or continuous cropping systems (Drechsel et al., 1996; van Noordwijk et al., 1995). However, tree fallows have distinct advantages over herbaceous fallows, particularly in seasonally dry climates, because they may take up nutrients from deep soil layers and recycle them better, and accumulate a large quantity of biomass (Szott et al., 1994); furthermore, leguminous tree fallows may add nitrogen to the system through BNF.

On Vertisols in semiarid India, one-year sole pigeonpea, harvested for grain, increased the subsequent maize yield by $57 \%$ compared with the yield after a bare fallow. The beneficial effect of pigeonpea, equivalent to the effect of $38 \mathrm{~kg} \mathrm{ha}^{-1}$ of fertilizer $\mathrm{N}$, was attributed to the enhanced mineralization of its post-harvest residues (Kumar Rao et al., 1983). In Malawi, a three-year-old pigeonpea fallow increased the yield of the following maize crop by 55\%, compared with natural fallow (Prinz, 1986). However, on Ultisols in Nigeria, while a two-year fallow of $T$. candida increased the yield of subsequent maize by $1.5 \mathrm{Mg} \mathrm{ha}^{-1}$ (or 157\%) compared with bush fallow, a two-year pigeonpea 
fallow did not show any benefit (Gichuru, 1991). Tephrosia vogelii was found to be promising in Rwanda, where its one-year fallow increased yield of the first sequential crop (maize) by $72 \%$ over control and the second crop (bean) by $96 \%$ (Balasubramanian and Sekayange, 1992). In researcher-managed plots, residual effects of fallows ranged from $40 \%$ to $170 \%$ in the first season and $42 \%$ to $84 \%$ in the second season (Drechsel et al., 1996). However, yield increases on farms following one-year fallows did not compensate for the loss of two crops during the fallow period (Drechsel et al., 1996).

In Zambia, one-year sesbania fallows increased the subsequent maize yields by $50 \%$ to $80 \%$, and two-year fallows by $150 \%$ to $270 \%$ over the control maize yields after a grass fallow or continuous cropping (Kwesiga and Coe, 1994; Torquebiau and Kwesiga, 1996). The residual effect of both one- and twoyear fallows was observed even four years after clearing the fallow, with three times higher yield than in monocropped maize (Kwesiga et al., 1998). Such a large residual effect more than compensates for the loss of production during the fallow period. In western Kenya, 18 months of sesbania fallow has produced in the subsequent three seasons $9.7 \mathrm{Mg} \mathrm{ha}^{-1}$ of maize compared with $6.9 \mathrm{Mg} \mathrm{ha}^{-1}$ after a grass fallow and $4.9 \mathrm{Mg} \mathrm{ha}^{-1}$ after continuous maize cropping. The fallow effect at this P-deficient site was substantially higher after applying P fertilizer to maize (B.A. Jama, pers.comm., 1997).

Pruning of trees during the fallow phase might increase the production of foliar biomass for greater in situ nutrient cycling at the expense of wood, which is normally taken out of the field. In western Kenya, Onim et al. (1990) pruned the fallows of sesbania, leucaena and pigeonpea at two-month intervals and incorporated the prunings into the soil. Following a one-year fallow, they recorded yield increases of $67 \%$ in the first crop of maize, compared with yields after a natural fallow. There was no residual effect in the second crop of maize, but a $26 \%$ yield increase was noted in the third crop of beans after leucaena and sesbania fallows; this could be an effect of the tree-crop rotation. Root biomass of fallow trees might contribute substantially to the residual effect of fallows over the years. Sanginga et al. (1988) estimated the N contribution of roots, nodules and, probably, a small percent of leaf litter of leucaena fallow to be equivalent to $32 \mathrm{~kg} \mathrm{~N} \mathrm{ha}^{-1}$ on maize, similar to that of aboveground prunings in HI. Inoculated leucaena exhibited a greater effect than uninoculated leucaena.

The potential of short-duration tree fallows to restore soil productivity and increase yields of food crops has not been adequately explored in the humid tropics. Because soil degradation occurs rapidly in the humid tropics, longer duration fallows may be required to achieve the desired effect on subsequent crops. On Typic Paleudults in Peru, the total yield of three continuous crops (two rice and one cowpea) following 4.5-year inga and desmodium (Desmodium ovalifolium) fallows was $34 \%$ and $21 \%$ higher, respectively, than the yield after secondary forest of the same duration, due to higher rates of N mineralization following planted fallows (Szott and Meléndez, 1991).

A rotational woodlot-intercrop system has been developed in the Shinyanga 
region of Tanzania, in which the woodlot is intercropped with annual crops for two to three years in the early stage of tree growth and again after the harvest of trees two to three years later, keeping the stumps very low. Following a four-year-old mixed stand of Acacia polyacantha and leucaena, the first crop of maize gave 100\% and the second crop 16\% higher yields than the crops after a grass fallow (ICRAF, 1995). When yields decline to an uneconomical level, the stumps can be allowed to regrow into a woodlot.

Increased maize yields for one or two years have been reported following three to four years of Chromolaena odorata fallows in the Täi region of Ivory Coast (Slaats, 1996). This beneficial 'weed fallow,' which establishes rapidly by natural regeneration, could help intensify cropping in the humid tropics of Central and West Africa and Southeast Asia, where slash-and-burn is currently in vogue. However, it is not known if the positive effects of fallows with nonleguminous species such as chromolaena are short-lived or if they will sustain increased crop yields over successive fallow-cropping cycles. The issue of BNF may not be important for fallow species where the soils contain large quantities of accumulated nutrients at depth or are inherently fertile except for physical degradation. In these situations, tree species that efficiently recycle nutrients from depth, improve soil physical and biological conditions rapidly, and suppress weeds quickly are appropriate for use in tree fallows. In nitrogen-depleted soils, however, species that have high BNF ability should be preferred.

\section{Conclusions}

In the absence of direct competition between trees and crops for growth resources, sequential agroforestry systems offer an opportunity for exploiting the potential soil ameliorative attributes of trees for enhancing crop production. Soil amelioration is based primarily on $\mathrm{N}$ replenishment through BNF and recycling of $\mathrm{N}, \mathrm{P}$ and basic cations to the crop root zone, and secondarily on improved soil physical conditions and biological activity. While chemical fertility is important in nutrient-depleted soils, the physical and biological aspects of soil fertility become more important in degraded soils. Tree fallows reduce weed populations through shading, which helps in the rehabilitation of abandoned grasslands.

On inherently fertile but nutrient-depleted soils, one- to two-year fallows with fast-growing leguminous shrubs, such as sesbania, can replenish soil $\mathrm{N}$ stocks to a level adequate for the production of 3 to $4 \mathrm{Mg} \mathrm{ha}^{-1}$ of maize during the first cropping season and for substantially increased yields of subsequent crops, compared with grass fallow or continuous cropping. The residual effect of such fallows can extend for up to four years after the removal of fallow, offsetting the loss of production during the fallow period and increasing the attractiveness of tree fallows to farmers. On infertile soils, tree fallows require a longer period to improve soil fertility. Tree fallows, however, do not increase the supply of $\mathrm{P}$ in the soil, although they may increase $\mathrm{P}$ availability within the system. Therefore, crops that follow tree fallows on P-deficient soils will 
need $\mathrm{P}$ fertilizers to fully exploit the potential benefits resulting from the fallow. Tree species that grow fast, fix nitrogen, root deeply, produce high root biomass and high quality foliar biomass, and provide economically valuable byproducts (e.g., fodder, fuelwood) are well suited for short-duration fallows.

\section{Future research directions}

This review has described the progress that has been made during the past 10 to 15 years in research efforts to increase and apply our knowledge of biophysical interactions in major tropical agroforestry systems and technologies. Obviously, all systems and technologies have not received equal attention during that period; for example, while $\mathrm{HI}$ has been explored widely and intensively since the early 1980s, planted fallows have been researched only since the late 1980s, and multistrata systems and others involving tree-livestock interactions have been little studied. Nevertheless, we have a much better understanding today than we had ten years ago with respect to the broad geographical and ecological limits and constraints of some of the evolving technologies, as well as the major interactions in each of them. Further effort is required to develop management practices in participation with farmers that will maximize complementary interactions and resolve the location-specific constraints to widespread adoption of the technologies. Intermediate agroforestry technologies might be more appropriate than straightforward HI or tree fallow systems for certain conditions. For example, HI could be rotated with tree fallows, or intercropping systems using coppiced trees or widely spaced rows of trees could be rotated with tree fallows or woodlots (using the already established trees).

As research in tropical agroforestry takes new directions, research on interactions will follow suit. Tropical agroforestry research has so far placed high emphasis on technologies that stress the service functions of trees for soil fertility improvement and/or soil conservation. Too little attention has been given to high-value or income-generating trees. Future research will concentrate on technologies involving high-value fruit, pole, and medicinal trees that can be integrated with crops, and biophysical interaction research will adopt the same focus. Secondly, there is need to examine the potential of exploiting inter- and intraspecies genetic variation in trees. The choice of tree species is an important management decision that determines the success or failure of a technology at a given place. Although the number of tree species explored in agroforestry research has increased substantially in recent years, much remains to be done. The usefulness of mixing species for hedgerow and fallow technologies needs to be evaluated. Mixing of species with different growth habits, rooting patterns, and quality of leaf residues may lead to higher biomass productivity by enhancing complementary use of growth resources, reducing pest problems, and promoting greater synchrony in the release of nutrients 
from residues in relation to crop requirements. Similarly, the range of crops used for testing the potential of agroforestry technologies meant for soil fertility improvement has been limited almost exclusively to cereals (mostly maize), despite the fact that even these crops, in practice, are grown either in rotation with or mixed with legumes. Continuous cultivation of cereal crops (in control treatments) depletes soil nutrients much faster than systems with cereal-legume rotations, and may lead to overestimation of the benefits of agroforestry treatments.

There is still inadequate understanding of belowground biophysical interactions in tropical agroforestry systems, but this area is now receiving considerable research attention. Progress has been made in recent years in the development of both the concepts and the techniques for belowgroundinteraction studies. Conceptually, a so-called 'central' hypothesis to justify agroforestry is that trees must utilize resources such as water and nutrients that are not utilized by crops (Cannell et al., 1996). This means that if the existing resources are under-utilized or unutilized in a crop-only system because they are inaccessible to crop roots, then spatial and/or temporal differences in rooting and root dynamics in an agroforestry system (complementarity) would be an advantage. For example, research on improved fallows in western Kenya showed that when growth of striga-infested maize was poor, large amounts of $\mathrm{N}$ remained unutilized and was eventually leached from the root zone (ICRAF, 1996). In terms of techniques for belowground-interaction studies, some of the recent developments such as simple allometric or fractal methods for quantifying root architecture (van Noordwijk and Purnomosidhi, 1995) and the low-cost heat-pulse technique for measuring root functioning (Khan and Ong, 1996) will be of value in the future. These techniques should be helpful in efforts to screen conveniently a large number of tree species or provenances suitable for simultaneous systems. A related development is in the area of modeling of biophysical interaction processes in agroforestry systems (Lawson et al., 1995). Further progress in model development and validation will, however, depend very much on the availability of physiological data (especially root structure and functioning) for the trees that are used in the systems. The various modelling efforts currently underway should help integrate the large body of data that is now available and increase our predictive understanding of agroforestry systems to guide future research and delineate biophysical limits for promising technologies.

Few studies have been published on the role of soil fauna, the functions of specific groups, and the scope for their manipulation for improving soil physical properties and nutrient availability to crops. With regard to sequential systems, although research has demonstrated the potential of fallows to improve soil fertility, knowledge on how fallows work in different soil and climatic conditions is still inadequate. Some issues that deserve further attention are (1) the relative importance of soil chemical, physical and biological changes that tree fallows cause in different soil and climatic conditions; (2) the length of residual effects of fallows of different durations; (3) the 'fate' 
of nitrogen in the system; (4) the external nutrients required for the sustainable function of fallows; and (5) the specific 'rotational effects' of fallows, for example, the control of pests and diseases. Short-term fallows may not have any specific advantage over annual crops in terms of carbon sequestration, but medium- to long-term tree fallows may have a favorable effect on the soil $\mathrm{C}$ budget and it needs to be quantified.

Another aspect that has not received adequate attention is the time and spatial dimension of biophysical interactions in agroforestry. Most studies have been conducted for only a few years, whereas agroforestry technologies must be evaluated on a long-term basis. Similarly, most information on biophysical interactions in agroforestry, as reviewed here, is based on plot-level studies. The interactions of systems at farm and landscape level should receive attention in the future because the lateral flow of resources (e.g., water and nutrients) becomes important at such spatial scales and because trees can exploit resources from larger areas than allocated (van Noordwijk and Ong, 1996). Knowledge of the larger-scale interactions is important in order to realistically assess the community and global benefits of agroforestry.

To date, most knowledge of biophysical interactions in agroforestry systems has come from studies of simultaneous or sequential systems which involve only two sets of components - the tree and the crop. The complexity and enormity of the task of studying biophysical interactions will be increased many-fold when research efforts are extended to multistrata systems such as homegardens and whole farms, including livestock. Furthermore, although it has not been discussed in this paper, the adoption of technologies that exploit interactions is an important issue. It is well known that the extent of adoption of any technology will depend not only on the magnitude of positive biophysical benefits, but also on a number of socioeconomic factors. Biophysical (interaction) research in agroforestry will inevitably and increasingly be linked to socioeconomic (interaction) research in the future.

\section{Acknowledgments}

The authors sincerely thank Pedro Sanchez, Meine van Noordwijk and John

Beer for providing valuable comments on the drafts of this paper.

\section{References}

Ae N, Arihara J, Okada K, Yoshihara T and Johansen C (1990) Phosphorus uptake by pigeonpea and its role in cropping systems of the Indian subcontinent. Science 248: 477-480

Adejuwan JO and Adesina FA (1990) Organic matter and nutrient status under cultivated fallows: an example of Gliricidia sepium fallows from South Western Nigeria. Agroforestry Systems 10: $23-32$

Akobundu IO and Ekeleme FE (1996) Potentials for Chromolaena odorata (L.) R. M. King and H. Robinson in fallow management in West and central Africa. In: Prasad UK, 
Muniappan R, Ferrar P, Aechliman JP and de Foresta H (eds) Distribution, Ecology and Management of Chromolaena odorata, pp 88-98, Publication No. 202, University of Guam, Mangilao, Guam, USA

Aggarwal RK (1980) Physicochemical status of soils under khejri (Prosopis cineraria Linn.). In: Mann HS and Saxena SK (eds), Khejri (Prosopis cineraria) in the Indian Desert, pp 32-37, Central Arid Zone Research Institute, Jodhpur, India

Akinnifesi FK, Kang BT, Sanginga N and Tijani-Eniola H (1997) Nitrogen use and Ncompetition between Leucaena hedgerows and maize in an alley cropping system. Nutrient Cycling in Agroecosystems 47: 71-80.

Akyeampong E, Duguma B, Heineman AM, Kamara CS, Kiepe P, Kwesiga F, Ong CK, Otieno HJ and Rao MR (1995a) A synthesis of ICRAF's research on alley cropping. In: Kang BT, Osiname AO and Larbi A (eds) Alley Farming Research and Development, pp 40-51, IITA, Ibadan, Nigeria

Akyeampong A and Hitimana L (1996) Agronomic and economic appraisal of alley cropping with Leucaena diversifolia on an acid soil in the highlands of Burundi. Agroforestry Systems 33: $1-11$

Akyeampong A, Hitimana L, Franzel S and Munyemana PC (1995b) The agronomic and economic performance of banana, bean and tree intercropping in the highlands of Burundi: an interim assessment. Agroforestry Systems 31: 199-210

Akondé TP, Leihner DE and Steinmüller N (1996) Alley cropping on an Ultisol in subhumid Benin: Part 1: Long-term effect on maize, cassava and tree productivity. Agroforestry Systems 34: $1-12$

Alegre JC and Rao MR (1996) Soil and water conservation by contour hedging in the humid tropics of Peru. Agriculture, Ecosystems and Environment 57: 17-25

Anderson LS and Sinclair FL (1993) Ecological interactions in agroforestry systems. Agroforestry Abstracts 6: 57-91

Anoka UA, Akobundu IO and Okonkwo SNC (1991) Effects of Gliricidia sepium (Jacq.) Steud and Leucaena leucocephala (Lam.) de Wit on growth and development of Imperata cylindrica (L.) Raeuschel. Agroforestry Systems 16: 1-12

Balasubramanian V and Sekayange L (1991) Effects of tree legumes in hedgerows on soil fertility changes and crop performance in the semi-arid highlands of Rwanda. Biological Agriculture and Horticulture 8: 17-32

Balasubramanian V and Sekayange L (1992) Five years of research on improved fallow in the semi-arid highlands of Rwanda. In: Mulongoy K, Gueye M and Spencer DSC (eds) Biological Nitrogen Fixation and Sustainability of Tropical Agriculture, pp 405-422, John Wiley \& Sons and Sayce Publishing, Chichester, UK

Banda AZ, Maghembe JA, Ngugi DN and Chome VA (1994) Effect of intercropping of maize and closely spaced leucaena hedgerows on soil conservation and maize yield on a steep slope at Ntcheu, Malawi. Agroforestry Systems 27: 17-22

Beer JW, Muschler RG, Kass DCL and Somarriba EJ (1997) Shade management in coffee and cacao plantations. Agroforestry Systems 38: 139-164

Belsky AJ, Mwonga SM and Duxbury JM (1993) Effects of widely spaced trees and livestock grazing on understory environments in tropical savannas. Agroforestry Systems 24: $1-20$

Bhatt BP and Todaria NP (1990) Studies on the allelopathic effects of some agroforestry tree crops of Garhwal Himalaya. Agroforestry Systems 12: 251-255

Bolan NS (1991) A critical review on the role of mycorrhizal fungi in the uptake of phosphorus by plants. Plant and Soil 134: 189-207

Breman H and Kessler JJ (1995) Woody Plants in Agro-ecosystems of Semi-arid Regions. Springer-Verlag, Berlin Heidelberg

Brouwer J, Geiger SC and Vandenbeldt RJ (1992) Variability in the growth of Faidherbia albida: a termite connection. In: Vandenbeldt RJ (ed) Faidherbia albida in the West African Semi-arid Tropics, pp 131-138. ICRISAT, Patancheru-502 324, A.P., India 
Bunderson WT (1992) Final report of the agroforestry technical assistance to the national agroforestry team, MARE project, Chitedze Agricultural Research Station, Malawi

Buresh RJ and Tian G (1997) Soil improvement by trees in sub-Saharan Africa. Agroforestry Systems 38: 51-76

Campbell BM, Frost P, King JA, Mawanza M and Mhlanga L (1994) The influence of trees on soil fertility on two contrasting semi-arid soil types at Matopos, Zimbabwe. Agroforestry Systems 28: 159-172

Cannell MGR, van Noordwijk M and Ong CK (1996) The central hypothesis: trees must acquire resources that the crop would not otherwise acquire. Agroforestry Systems 33: 27-31

Charreau C and Vidal P (1965) Influence de l'Acacia albida Del. sur le sol: nutrition minéral et rendements des mils Pennisetum au Sénégal. Agronomie Tropicale 6-7: 600-626

Chiyenda S and Materechera SA (1989) Some results from alley cropping Leucaena leucocephala, Cassia siamea and Cajanus cajan with maize at Bunda college of agriculture. In: Trees for Development in Sub-Saharan Africa, pp 135-142, IFS, Stockholm, Sweden

Cooper PJM, Leakey RRB, Rao MR and Reynolds L (1996) Agroforestry and the mitigation of land degradation in the humid and subhumid tropics of Africa. Experimental Agriculture 32: $235-290$

Craswell E (1997) Agroforestry in the management of sloping lands in Asia and the Pacific. Agroforestry Systems 38: 121-137

CTFT (1988) Faidherbia albida (Del.) A. Chev. (synonyme Acacia albida Del.). Centre Technique Forestier Tropical, Nogent-sur-Marne, France

Dalland A, Våje PI, Mathews RB and Singh BR (1993) The potential of alley cropping in improvement of cultivation systems in the high rainfall areas of Zambia. III. Effects on soil chemical and physical properties. Agroforestry Systems 21: 117-132

Depommier D, Janodet E and Oliver R (1992) Faidherbia albida parks and their influence on soils and crops at Watinoma, Burkina Faso. In: Vandenbeldt RJ (ed) Faidherbia albida in the West African Semi-arid Tropics, pp 111-116, ICRISAT, Patancheru-502 324, A.P., India

De Rouw A (1995) The fallow period as a weed-break in shifting cultivation (tropical wet forests). Agriculture, Ecosystems and Environment 54: 31-43

Drechsel P, Glaser B and Zech W (1991) Effect of four multipurpose tree species on soil amelioration during tree fallow in central Togo. Agroforestry Systems 16: 193-202

Drechsel P, Steiner KG and Hagedorn F (1996) A review on the potential of improved fallows and green manure in Rwanda. Agroforestry Systems 33: 109-136

Dommergues YR (1995) Nitrogen fixation by trees in relation to soil nitrogen economy. Fertilizer Research 42: 215-230

Duguma B, Mollet M and Tiki Manga T (1994) Annual Progress Report, Institute of Agronomic Research (IRA) and International Centre for Research in Agroforestry (ICRAF), AFRENA Report, ICRAF, Nairobi, Kenya

Evensen CI, Dierolf TS and Yost RS (1995) Decreasing rice and cowpea yields in alley cropping on highly weathered Oxisol in West Sumatra, Indonesia. Agroforestry Systems 31: 1-19

Fernandes ECM, Davey CB and Nelson LA (1993) Alley cropping on an acid soil in the upper Amazon: mulch, fertilizer, and hedgerow root pruning effects. In: Technologies for Sustainable Agriculture in the Tropics, pp 77-96, ASA Special Publication 56, American Society of Agronomy, Madison, WI 53711, USA

Garrity, DP (ed) (1997) Agroforestry innovations for Imperata grassland rehabilitation. Agroforestry Systems (Special Issue) 36: 1-274

Geiger SC, Vandenbeldt RJ and Manu A (1994) Variability in the growth of Faidherbia albida: the soils connection. Soil Science Society of America Journal 58: 227-231

Groot JJR and Soumare A (1995) The roots of the matter: soil quality and tree roots in the Sahel. Agroforestry Today 7(1): 9-11

Gichuru MP (1991) Residual effects of natural bush, Cajanus cajan and Tephrosia candida on the productivity of an acid soil in southeastern Nigeria. Plant and Soil 134: 31-36 
Govindarajan M, Rao MR, Mathuva MN and Nair PKR (1996) Soil-water and root dynamics under hedgerow intercropping in semiarid Kenya. Agronomy Journal 88: 513-520

Haggar JP, Warren GP, Beer JW and Kass D (1991) Phosphorus availability under alley cropping and mulched and unmulched sole cropped systems in Costa Rica. Plant and Soil 137: 275-283

Hands MR, Harrison AF and Bayliss-Smith T (1995) Phosphorus dynamics in slash-and-burn and alley cropping systems of the humid tropics. In: Tiessen $\mathrm{H}$ (ed) Phosphorus in the Global Environment: Transfers, Cycles and Management, pp 155-170, John Wiley, New York

Hauser S (1993) Distribution and activity of earthworms and contribution to nutrient cycling in alley cropping. Biology and Fertility of Soils 15: 16-20

Hauser S and Kang BT (1993) Nutrient dynamics, maize yield and soil organic matter dynamics in alley cropping with Leucaena leucocephala. In: Mulongoy K and Merckx R (eds) Soil Organic Matter Dynamics and Sustainability of Tropical Agriculture, pp 215-222. John Wiley \& Sons and Sayce Publishing, Chichester, UK

Hulugalle NR and Kang BT (1990) Effect of hedgerow species in alley cropping systems on surface soil physical properties of an Oxic Paleustalf in southwestern Nigeria. Journal of Agricultural Science (Cambridge, UK) 114: 301-307

Hulugalle NR and Ndi JN (1993) Effects of no-tillage and alley cropping on soil properties and crop yields in a Typic Kandiudult of southern Cameroon. Agroforestry Systems 22: 207-220

Huxley PA, Pinney A, Akunda E and Muraya P (1994) A tree/crop interface orientation experiment with a Grevillea robusta hedgerow and maize. Agroforestry Systems 26: 23-45

ICRAF (1995) Annual Report for 1994, pp 91-93, 153-154. International Centre for Research in Agroforestry, Nairobi, Kenya

ICRAF (1996) Annual Report for 1995, pp 83-88, 64-69, 172-180, 207-210. International Centre for Research in Agroforestry, Nairobi, Kenya

ICRAF (1997) Annual Report for 1996. International Centre for Research in Agroforestry, Nairobi, Kenya

Jama B, Getahun A and Ngugi DN (1991) Shading effects of alley cropped Leucaena leucocephala on weed biomass and maize yield at Mtwapa, Coast Province, Kenya. Agroforestry Systems 13: 1-11

Jama B, Nair PKR and Rao MR (1995) Productivity of hedgerow shrubs and maize under alleycropping and block planting systems in semiarid Kenya. Agroforestry Systems 31: $257-274$

Jonsson K, Ong CK and Odongo JCW (1997) Tree-crop interactions in a parkland system with millet, néré and karité in Burkina Faso. Experimental Agriculture (in press)

Jonsson K, Ståhl L and Hägberg P (1996) Tree fallows: a comparison between five tropical tree species. Biology and Fertility of Soils 23: 50-56

Juo ASR, Franzluebbers K, Dabiri A and Ikhile B (1996) Soil properties and crop performance on a kaolinitic Alfisol after 15 years of fallow and continuous cultivation. Plant and Soil 180: 209-217

Kamara CS and Haque I (1992) Faidherbia albida and its effects on Ethiopian highland Vertisols. Agroforestry Systems 18: 17-29

Kang BT (1993) Alley cropping: past achievements and future directions. Agroforestry Systems 23: $141-155$

Kang BT, Akinnifesi FK and Pleysier JL (1994) Effect of agroforestry woody species on earthworm activity and physicochemical properties of worm casts. Biology and Fertility of Soils 18: 193-199

Kang BT, Reynolds L and Atta-Krah AN (1990) Alley farming. Advances in Agronomy 43: 315-359

Kass DL, Araya JS, Sanchez JO, Pinto LS and Ferreira P (1995) Ten years experience with alley farming in Central America. In: Kang BT, Osiname AO and Larbi A (eds) Alley Farming Research and Development, pp 393-402, IITA, Ibadan, Nigeria 
Kater LJM, Kante S and Budelman A (1992) Karité (Vitellaria paradoxa) and néré (Parkia biglobosa) associated with crops in South Mali. Agroforestry Systems 18: 89-105

Kessler JJ (1992) The influence of karité (Vitellaria paradoxa) and néré (Parkia biglobosa) trees on sorghum production in Burkina Faso. Agroforestry Systems 17: 97-118

Kiepe P and Rao MR (1994) Management of agroforestry for the conservation and utilization of land and water resources. Outlook in Agriculture 23(1): 17-25

Khan AAH and Ong CK (1996) A low cost heat pulse method for measuring tree root water uptake. Agroforestry Forum 7(2): 19-22

Khanna PK (1997) Nutrient cycling under mixed-species tree systems in southeast Asia. Agroforestry Systems 38: 99-120

Khybri ML, Gupta RK, Sewa Ram and Tomar HPS (1992) Crop yields of rice and wheat grown in rotation as intercrops with three tree species in the outer hills of western Himalaya. Agroforestry Systems 17: 193-204

Kumar Rao JVDK, Dart PJ and Sastry PVSS (1983) Residual effect of pigeonpea (Cajanus cajan) on yield and nitrogen response of maize. Experimental Agriculture 19: 131-141

Kwesiga F and Coe R (1994) The effect of short rotation Sesbania sesban planted fallows on maize yield. Forest Ecology and Management 64: 199-208

Kwesiga F, Franzel S, Place F, Phiri D and Simwanza CP (1998) Sesbania sesban improved fallows in eastern Zambia: their inception, development and farmer enthusiasm. Agroforestry Systems (this issue)

Laike A (1992) Faidherbia albida in the traditional farming systems of central Ethiopia. In: Vandenbeldt RJ (ed) Faidherbia albida in the West African Semi-arid Tropics, pp 39-42, ICRISAT, Patancheru-502 324, A.P., India

Lal R (1989a) Agroforestry systems and soil surface management of a tropical alfisol. I. Soil moisture and crop yields. Agroforestry Systems 8: 7-29

Lal R (1989b) Agroforestry systems and soil surface management of a tropical alfisol. II. Water runoff, soil erosion and nutrient loss. Agroforestry Systems 8: 97-111

Lal R (1989c) Agroforestry systems and soil surface management of a tropical alfisol: III. Changes in soil chemical properties. Agroforestry Systems 8: 113-132

Lal R (1989d) Agroforestry systems and soil surface management of a tropical alfisol: IV. Effects on soil physical and mechanical properties. Agroforestry Systems 8: 197-215

Lal R (1989e) Agroforestry systems and soil surface management of a tropical alfisol: V. Water infiltrability, transmissivity and soil water sorptivity. Agroforestry Systems 8: 217-238

Lawson TL and Kang BT (1990) Yield of maize and cowpea in an alley cropping system in relation to available light. Agricultural and Forest Meteorology 52: 347-357

Lawson GJ, Crout NMJ, Levy PE, Mobbs DC, Wallace JS, Cannell MGR and Bradley RG (1995) The tree-crop interface: representation by coupling of forest and crop process models. Agroforestry Systems 30: 199-221

Malik RS and Sharma SK (1990) Moisture extraction and crop yield as a function of distance from a row of Eucalyptus tereticornis. Agroforestry Systems 12: 187-195

Mapa RB and Gunasena HPM (1995) Effects of alley cropping on soil aggregate stability of a tropical Alfisol. Agroforestry Systems 32: 237-245

Mason PA and Wilson J (1994) Harnessing symbiotic associations: vesicular-arbuscular mycorrhizas. In: Leakey RRB and Newton AC (eds) Tropical Trees: the Potential for Domestication and the Rebuilding of Forest Resources, pp 165-175, HMSO, London, UK

Mathuva MN, Rao MR, Smithson PC and Coe R (1997) Improving maize yields in semi-arid highlands of Kenya: agroforestry or fertilizers? Field Crops Research (in press)

Matthews RB Holden ST, Volk J and Lungu S (1992a) The potential of alley cropping in improvement of cultivation systems in the high rainfall areas of Zambia. I. Chitemene and Fundikila. Agroforestry Systems 17: 219-240

Matthews RB, Lungu S, Volk J, Holden ST and Solberg K (1992b) The potential of alley cropping in improvement of cultivation systems in the high rainfall areas of Zambia. II. Maize production. Agroforestry Systems 17: 241-262 
McIntyre BD, Riha SJ and Ong CK (1997) Competition for water in a hedge-intercrop system. Field Crops Research 52: 151-160

Miller RR and Hepburn AJ (1991) A review of the growth of Acacia mangium at the Bengkoka afforestation and settlement project North Sabah. In: Abod SA, Tahir PM, Tsai LM, Shukor NAA, Sajap AS and Manikam D (eds) Recent Developments in Tree Plantations of Humid/Subhumid Tropics of Asia, pp 93-99, Universiti Pertanian Malaysia

Mittal SP and Singh P (1989) Intercropping field crops between rows of Leucaena leucocephala under rainfed conditions in northern India. Agroforestry Systems 8: 165-172

Montagnini F and Sancho F (1990) Impacts of native trees on tropical soils: a study in the Atlantic lowlands of Costa Rica. Ambio 19 (8): 386-390

Monteith JL, Ong CK and Corlett JE (1991) Microclimate interactions in agroforestry. Forest Ecology and Management 45: 31-44

Mugendi DN, Mochoge BO, Coulson CL and Sang FK (1997) Effect of incorporating Cassia siamea prunings on maize yield in semiarid Kenya. African Crop Science Journal 5: 271-277

Mulongoy K, Kunda KN and Chiang CNK (1993) Effect of alley cropping and fallowing on some soil fertility parameters in southern Nigeria. In: Mulongoy K and Merckx R (eds) Soil Organic Matter Dynamics and Sustainability of Tropical Agriculture, pp 47-56, John Wiley \& Sons and Sayce Publishing, Chichester, UK

Mulongoy K and van der Meersch MK (1988) Nitrogen contribution by leucaena (Leucaena leucocephala) prunings to maize in an alley cropping system. Biology and Fertility of Soils 6: $282-285$

Mureithi JG, Taylor RS and Thorpe W (1994) The effects of alley cropping with Leucaena leucocephala and of different management practices on the productivity of maize and soil chemical properties in lowland coastal Kenya. Agroforestry Systems 27: 31-52

Nair PKR (ed) (1989) Agroforestry Systems in the Tropics. Kluwer Academic Publishers, Dordrecht, The Netherlands

Nair PKR (1990) The Prospects for Agroforestry in the Tropics. Technical Paper No. 131: World Bank, Washington, DC, USA

Nair PKR (1991) State-of-the-art of agroforestry systems. Forest Ecology and Management 45: $5-29$

Nair PKR (1993) An Introduction to Agroforestry. Kluwer Academic Publishers, Dordrecht, The Netherlands

Nair PKR, Rao MR and Fernandes ECM (1994) Tree-crop interactions in sustainable agroforestry systems. In: Soil Technology for Sustainable Agriculture, Symposia VIa, ISSS Commission VI: Soil Technology, pp 110-137, 15th International Congress of Soil Science, 10-16 July 1994, Acapulco, Mexico

Nandal DPS, Bisla SS, Narwal SS and Kaushik JC (1994) Allelopathic interactions in agroforestry systems. In: Narwal SS and Tauro P (eds) Allelopathy in Agriculture and Forestry, pp 92-130, Scientific Publishers, Jodhpur, India

Nygren P and Jiménez JM (1993) Radiation regime and nitrogen supply in modelled alley cropping systems of Erythrina poeppigiana with sequential maize-bean cultivation. Agroforestry Systems 21: 271-285

Obondo L (1987) Potencial alelopatico de Gliricidia sepium (Jacq.) Walp. sobre los cultivo de maiz y frijol y las malezas predominantes. In: Withington D, Glover $\mathrm{N}$ and Brewbaker JL (eds), pp 59-60, Gliricidia sepium (Jacq.) Walp. Management and Improvement, Nitrogen Fixing Tree Association, Waimanalo, Hawaii, USA

Okorio J, Byenkya S, Wajja N and Peden D (1994) Comparative performance of seventeen upperstorey tree species associated with crops in the highlands of Uganda. Agroforestry Systems 26: 185-203

Okorio J and Maghembe JA (1994) The growth and yield of Acacia albida intercropped with maize (Zea mays) and beans (Phaseolus vulgaris) at Morogoro, Tanzania. Forest Ecology and Management 64: 183-190 
Ong CK and Huxley P (eds) (1996) Tree-Crop Interactions: A Physiological Approach. CAB International, Wallingford, UK

Ong CK and Black CR (1994) Complementarity in resource use in intercropping and agroforestry systems. In: Monteith JL, Scott RK and Unsworth MH (eds) Resource Capture by Crops, pp 255-278, Nottingham University Press, Loughborough, UK

Ong CK, Corlett JE, Singh RP and Black CR (1991) Above and below ground interactions in agroforestry systems. Forest Ecology and Management 45: 45-57

Onim JFM, Mathuva M, Otieno K and Fitzhugh HA (1990) Soil fertility changes and response of maize and beans to green manures of leucaena, sesbania and pigeonpea. Agroforestry Systems 12: 197-215

Oswald A, Frost H, Ransom JK, Kroschel J, Shepherd KD and Sauerborn J (1996) Studies on the potential for improved fallow using trees and shrubs to reduce striga infestations in Kenya. In: Moreno MT, Cubero JI, Berner D, Joel D, Musselman LJ and Parker C (eds) Advances in Parasitic Plant Research, pp 795-780, Junta de Andalucia, Codoba, Spain

Palm CA (1995) Contribution of agroforestry trees to nutrient requirements of intercropped plants. Agroforestry Systems 30: 105-124

Palm CA, Salazar AA, Szott LT and Fernandes ECM (1995) Long-term performance of alley cropping on acid soils of the Amazon basin. In: Kang BT, Osiname AO and Larbi A (eds) Alley Farming Research and Development, pp 379-392, IITA, Ibadan, Nigeria

Poschen, P (1986) An evaluation of the Acacia albida-based agroforestry practices in the Hararghe highlands of eastern Ethiopia. Agroforestry Systems 4: 129-143

Prinz D (1986) Increasing the productivity of smallholder farming systems by introduction of planted fallows. Plant Research and Development 24: 31-56

Puri S and Bangarwa KS (1992) Effects of trees on the yield of irrigated wheat crop in semiarid regions. Agroforestry Systems 20: 229-241

Putnam AR and Tang CS (1986) The Science of Allelopathy, Wiley, New York, USA

Ralhan PK, Singh A and Dhanda RS (1992) Performance of wheat as intercrop under poplar (Populus deltoides Bartr.) plantations in Punjab (India). Agroforestry Systems 19: 217-222

Ramakrishnan PS and Misra BK (1981) Population dynamics of Eupatorium adenophorum Spreng. during secondary succession after slash and burn agriculture (jhum) in northeastern India. Weed Research 22: 77-84

Rao DLN, Gill HS and Ibrol IP (1990) Regional experience with perennial Sesbania in India. In: Macklin B and Evans DO (eds), Perennial Sesbania Species in Agroforestry, pp 189-198, NFTA, Waimanalo, Hawaii, USA

Rao MR, Muraya P and Huxley PA (1993) Observations of some tree root systems in agroforestry intercrop situations, and their graphical representation. Experimental Agriculture 29: 183-194

Rao MR, Sharma MM and Ong CK (1990) A study of the potential of hedgerow intercropping in semi-arid India using a two-way systematic design. Agroforestry Systems 11: 243-258

Rao MR, Ong CK, Pathak P and Sharma MM (1991a) Productivity of annual cropping and agroforestry systems on a shallow Alfisol in semi-arid India. Agroforestry Systems 15: $51-63$

Rao MR, Sharma MM and Ong CK (1991b) A tree/crop interface design and its use for evaluating the potential of hedgerow intercropping. Agroforestry Systems 13: 143-158

Rhoades C (1995) Seasonal pattern of nitrogen mineralization and soil moisture beneath Faidherbia albida (syn. Acacia albida) in central Malawi. Agroforestry Systems 29: 133-145

Rice EL (1984) Allelopathy. Academic Press, New York, USA

Rippen M, Hagger JPH, Kass D and Köpke U (1994) Alley cropping and mulching with Erythrina poeppigiana (Walp.) O. F. Cook and Gliricidia sepium (Jacq.) Walp.: effects on maize/weed competition. Agroforestry Systems 23: 119-134

Rosecrance RC, Rogers S and Tofinga M (1992) Effects of alley cropped Calliandra calothyrsus and Gliricidia sepium hedgerows on weed growth, soil properties and taro yields in Western Samoa. Agroforestry Systems 19: 57-66 
Ruhigwa BA, Gichuru MP, Mambani B and Tariah NM (1992) Root distribution of Acioa barteri, Alchornea cordifolia, Cassia siamea and Gmelina arborea in an acid Ultisol. Agroforestry Systems 19: 67-78

Saka AR, Bunderson WT, Itimu OA, Phombeya HSK and Mbekeani Y (1994) The effects of Acacia albida on soils and maize grain yields under smallholder farm conditions in Malawi. Forest Ecology and Management 64: 217-230

Salazar A, Szott LT and Palm CA (1993) Crop-tree interactions in alley cropping systems on alluvial soils of the Upper Amazon Basin. Agroforestry Systems 22: 67-82

Sanchez PA (1995) Science in agroforestry. Agroforestry Systems 30: 5-55

Sanchez PA and Hailu M (1996) (eds) Alternatives to slash-and-burn agriculture. Agriculture, Ecosystems and Environment 58: 1-87

Sanginga NK, Mulongoy K and Ayanaba A (1988) Nitrogen contribution of leucaena/ rhizobium symbiosis to soil and subsequent maize crop. Plant and Soil 112: 137-141

Sanginga NK and Swift MJ (1992) Nutritional effects of Eucalyptus litter on the growth of maize (Zea mays). Agriculture, Ecosystems and Environment 41: 55-65

Schroth G and Zech W (1995) Above- and below-ground biomass dynamics in sole cropping and alleycropping system with Gliricidia sepium in semi-deciduous rainforest zone of West Africa. Agroforestry Systems 31: 181-198

Schroth G, Kolbe D, Pity B and Zech W (1995a) Searching for criteria for the selection of efficient tree species for fallow improvement, with special reference to carbon and nitrogen. Fertilizer Research 42: 297-314

Schroth G, Oliver R, Balle P, Gnahoua GM, Kanchenkanti N, Leduc B, Mallet B, Peltier R and Zech W (1995b) Alley cropping with Gliricidia sepium on a high base status soil following forest clearing: effects on soil conditions, plant nutrition and crop yields. Agroforestry Systems 32: 261-276

Schroth G, Kolbe D, Pity B, and Zech W (1996) Root system characteristics with agroforestry relevance of nine leguminous tree species and a spontaneous fallow in a semi-deciduous rainforest area of West Africa. Forest Ecology and Management 84: 199-208

Shannon DA, Vogel WO and Kabaluaba KN (1994) The effects of alley cropping and fertilizer application on continuously cropped maize. Tropical Agriculture 71: 163-169

Siaw DEKA, Kang BT and Okali OUU (1991) Alley cropping with Leucaena leucocephala (Lam.) De Wit and Acioa barteri (Hook. f.) Engl. Agroforestry Systems 14: 219-231

Singh A, Dhanda RS and Ralhan PK (1993) Performance of wheat varieties under poplar (Populus deltoides Bartr.) plantations in Punjab (India). Agroforestry Systems 22: 83-86

Singh G, Singh NT and Abrol IP (1994) Agroforestry techniques for the rehabilitation of degraded salt-affected lands in India. Land Degradation \& Rehabilitation 5: 223-242

Singh RP, Ong CK and Saharan N (1989) Above and below ground competitions in alleycropping in semi-arid India. Agroforestry Systems 9: 259-274

Singh Rathore MP (1995) Insect Pests in Agroforestry. Working Paper No. 70, ICRAF, Nairobi, Kenya

Slaats JJP (1996) The use of Chromolaena odorata as fallow in a semi-permanent system in South-West Côte d'Ivoire. In: Prasad UK, Muniappan R, Ferrar P, Aeschliman JP and de Foresta H (eds) Distribution, Ecology and Management of Chromolaena odorata, pp 68-75, Publication No. 202, University of Guam, Mangilao, Guam, USA

Soman P, Stomph TJ, Bidinger F and Fussel LK (1987) Improvement in stand establishment in pearl millet. In: Food Grain Production in the Semi-Arid Africa: Proceedings of the OAU/STRC-SAFGRAD International Drought Symposium, 17-23 May 1986, Nairobi, Kenya, pp 159-171, OAU/STRC-SAFGRAD, Ouagadougou, Burkina Faso

Staver C (1991) The role of weeds in the productivity of Amazonian bush fallow agriculture. Experimental Agriculture 27: 287-304

Szott LT and Meléndez G (1991) Crop yields, soil nitrogen mineralization and soil chemical properties following 4.5 years of managed leguminous fallows. In: TropSoils Technical Report, 1988-1989, pp 234-236, North Carolina State University, Raleigh, USA 
Szott LT, Palm CA and Buresh RJ (1998) Ecosystem fertility and fallow function. Agroforestry Systems (in press)

Szott LT, Palm CA and Davey CB (1994) Biomass and litter accumulation under managed and natural tropical fallows. Forest Ecology and Management 67: 177-190

Szott LT, Palm CA and Sanchez PA (1991) Agroforestry in acid soils of the humid tropics. Advances in Agronomy 45: 275-301

Tejwani KG (1994) Agroforestry in India. Oxford \& IBH Publishing Co Pvt Ltd, New Delhi, India

Tian G and Kang BT (1994) Evaluation of phytotoxic effects of Gliricidia sepium (Jacq.) Walp. prunings on maize and cowpea seedlings. Agroforestry Systems 26: 249-254

Tian G, Brussaard L and Kang BT (1993) Biological effects of plant residues with contrasting chemical composition under humid tropical conditions: effects on soil fauna. Soil Biology and Biochemistry 25: 731-738

Tiessen H, Salcedo IH and Sampaio EVSB (1992) Nutrient and soil organic matter decomposition dynamics under shifting cultivation in semi-arid northeastern Brazil. Agriculture, Ecosystems and Environment 38: 139-151

Tilander Y, Ouedraogo G and Yougma F (1995) Impact of tree coppicing on tree-crop competition in parkland and alley farming systems in semiarid Burkina Faso. Agroforestry Systems 30: 363-378

Timmer LA, Kessler JJ and Slingerland M (1996) Pruning of néré trees (Parkia biglobosa (Jacq.) Benth.) on the farmlands of Burkina Faso, West Africa. Agroforestry Systems 33: 87-98

Tomlinson H, Teklehaimanot Z, Traoré A and Olapade E (1995) Soil amelioration and root symbioses of Parkia biglobosa (Jacq.) Benth. in West Africa. Agroforestry Systems 30: 145-159

Torquebiau EF and Kwesiga F (1996) Root development in Sesbania sesban fallow-maize system in eastern Zambia. Agroforestry Systems 34: 193-211

Vandenbeldt RJ (ed.) (1992) Faidherbia albida in the West African Semi-Arid Tropics. ICRISAT, Patancheru-502 234, Andhra Pradesh, India and ICRAF, Nairobi, Kenya

Vandenbeldt RJ and Williams JH (1992) The effect of soil surface temperature on the growth of millet in relation to the effect of Faidherbia albida trees. Agriculture and Forest Meteorology 60: 93-100

van Noordwijk M and Ong CK (1996) Lateral resource flow and capture - the key to scaling up agroforestry results. Agroforestry Forum 7(3): 29-31

van Noordwijk M and Purnomosidhi P (1995) Root architecture in relation to tree-crop-soil interactions and shoot pruning in agroforestry. Agroforestry Systems 30: 161-173

van Noordwijk M, Widianto M, Heinen M and Hairiah K (1991) Old tree roots channels in acid soils in the humid tropics: important for crop root penetration, water infiltration and nitrogen management. Plant and Soil 134: 37-44

van Noordwijk M, Sitompul SM, Hairiah K, Listyarini E and Syekhfani MS (1995) Nitrogen supply from rotational or spatially zoned inclusion of Leguminosae for sustainable maize production on an acid soil in Indonesia. In: Date RA, Grundon NJ, Rayment GE and Probert ME (eds) Plant-Soil Interactions at Low pH, pp 779-784, Kluwer, Dordrecht, The Netherlands

Wallace JS (1996) The water balance of mixed tree-crop systems. In: Ong CK and Huxley PA (eds) Tree-Crop Interactions: A Physiological Approach, pp 189-233, CAB International, Wallingford, UK

Wallace JS, Jackson NA and Ong CK (1997) Soil evaporation in a Grevillea robusta agroforestry system. 2. Modeling the effects of a tree canopy. Agricultural and Forest Meteorology (in press).

Weston LA (1996) Utilization of allelopathy for weed management in agroecosystems. Agronomy Journal 88: 860-866

Willis RJ (1991) Research on allelopathy on Eucalyptus in India and Pakistan. Commonwealth Forest Review 70: 279-289 
Wong MTF, Akyeampong A, Nortcliff S, Rao MR and Swift RS (1995) Initial responses of maize and beans to decreased concentrations of monomeric inorganic aluminium with application of manure or tree prunings to an Oxisol in Burundi. Plant and Soil 171: 275-282

Woomer P, Bajah AN, Atta-Krah and Sanginga N (1995) Analysis and interpretation of alley farming network data from tropical Africa. In: Kang BT, Osiname AO and Larbi A (eds), Alley Farming Research and Development, pp 189-20, IITA, Ibadan, Nigeria

Xu ZH, Myers RJK, Saffinga PG and Chapman AL (1993a) Nitrogen fertilizer in leucaena alley cropping. II. Residual value of nitrogen fertilizer and leucaena residues. Fertilizer Research 34: 1-8

Xu ZH, Myers RJK, Saffinga PG and Chapman AL (1993b) Nitrogen cycling in leucaena (Leucaena leucocephala) alley cropping in semi-arid tropics. II. Response of maize growth to addition of nitrogen fertilizer and plant residues. Plant and Soil 148: 73-82

Yadav JP, Sharma KK and Khanna P (1993) Effect of Acacia nilotica on mustard crop. Agroforestry Systems 21: 91-98

Yamoah CF, Agboola AA and Mulongoy K (1986a) Decomposition, nitrogen release and weed control by prunings of selected alley cropping shrubs. Agroforestry Systems 4: 239-246

Yamoah CF, Agboola AA, Wilson, GF and Mulongoy K (1986b) Soil properties as affected by the use of leguminous shrubs for alley cropping with maize. Agriculture, Ecosystems and Environment 18: 167-177

Yobterik AC, Timmer VR and Gordon AM (1994) Screening agroforestry tree mulches for corn growth: a combined soil test, pot trial and plant analysis approach. Agroforestry Systems 25: $153-166$

Young A (1997) Agroforestry for Soil Management. CAB International, Wallingford, UK and ICRAF, Nairobi, Kenya 